\title{
Chemical Composition and Antioxidant and Antimicrobial Activities of Wormwood (Artemisia absinthium L.) Essential Oils and Phenolics
}

\author{
Kamel Msaada, ${ }^{1,2}$ Nidhal Salem, ${ }^{1}$ Olfa Bachrouch, ${ }^{1}$ Slim Bousselmi, ${ }^{1}$ \\ Sonia Tammar, ${ }^{1}$ Abdulkhaleg Alfaify, ${ }^{2}$ Khaldoun Al Sane, ${ }^{2}$ Wided Ben Ammar, ${ }^{3}$ \\ Sana Azeiz,, Adel Haj Brahim, ${ }^{1}$ Majdi Hammami, ${ }^{1}$ Sawsen Selmi, ${ }^{1}$ \\ Ferid Limam, ${ }^{1}$ and Brahim Marzouk ${ }^{1}$ \\ ${ }^{1}$ Laboratory of Bioactive Substances, Biotechnology Center in Borj-Cedria Technopol, BP 901, 2050 Hammam-Lif, Tunisia \\ ${ }^{2}$ Biology Department, College of Sciences, King Khalid University, P.O. Box 9004, Abha 61413, Saudi Arabia \\ ${ }^{3}$ Unit of Research "Nitrogenized Nutrition and Metabolism and Stress Proteins" UR 99/09-20, Department of Biology, \\ Faculty of Science, University of Tunis, 2092 Tunis, Tunisia
}

Correspondence should be addressed to Kamel Msaada; msaada_kamel@yahoo.fr

Received 15 December 2014; Revised 15 February 2015; Accepted 16 February 2015

Academic Editor: Augusto C. Tome

Copyright (C) 2015 Kamel Msaada et al. This is an open access article distributed under the Creative Commons Attribution License, which permits unrestricted use, distribution, and reproduction in any medium, provided the original work is properly cited.

\begin{abstract}
The aim of this study was to determine the chemical variability of wormwood extracts as affected by the growing region. Antioxidant and antimicrobial activities were also investigated. The essential oil composition variability of $A$. absinthium L. aerial parts collected from four different Tunisian regions was assessed by gas chromatography (GC/FID) and by gas chromatography mass spectrometry (GC/MS). In addition, total polyphenols, flavonoids, and condensed tannins as well as antioxidant, antibacterial, and antifungal activities of methanolic extract and essential oils were undertaken. Chromatographic analysis of wormwood essential oils showed the predominance of monoterpene hydrocarbons represented mainly by chamazulene. RP-HPLC analysis of wormwood methanolic extract revealed the predominance of phenolic acids. Antiradical activity was region-dependant and the methanolic extract of Bou Salem region has the strongest activity $\left(\mathrm{CI}_{50}=9.38 \pm 0.82 \mu \mathrm{g} / \mathrm{mL}\right)$. Concerning the reducing power, the methanolic extract of Bou Salem, Jérissa, and Boukornine regions was more active than the positive control. Obtained results of antimicrobial activities showed that wormwood essential oil is endowed with important antibacterial activity which was strongly related to the organoleptic quality of oil which appeared strongly region-dependant. A. absinthium L. EOs investigated are quite interesting from a pharmaceutical standpoint because of their biological activities.
\end{abstract}

\section{Introduction}

Artemisia absinthium L. (Asteraceae), commonly known as wormwood in United Kingdom and absinthe in France, is an aromatic, perennial small shrub. It is locally known as "chajret mariem" in Tunisia. The herb has always been of a great botanical and pharmaceutical interest and is employed in folk medicine against various paints [1]. Wormwood essential oil has been widely used mainly for its neuroprotective [2], antifungal [3], antimicrobial [4], insecticidal [3], acaricidal [5], anthelmintic [6], antimalarial [7], hepatoprotective [8], and antidepressant [9] proprieties. In addition, the herb is used to make a tea for helping pregnant women during pain of labor and in treating leukaemia and sclerosis [10]. Moreover, the organic extract of this herb revealed toxic and antifeedant effect on Leptinotarsa decemlineata [11]. It was always used as a drink in France called absinthe which caused dementia. In the 18th century, alcoholic decoctions of wormwood and other plants were used as all-purpose remedies or "cure-alls," but it was not until the beginning of the 19th century that the wormwood-flavored alcoholic extracts and distillates were seen not only as potent medicines, but also as aperitifs, and 
the large scale production of absinthe began. In addition, Artemisia absinthium L. was used freshly for the plant species, as well as for the alcoholic beverage.

Aromatic and medicinal plants are an easily accessible and edible source of natural antioxidants. They have the ability to protect the organism from damage caused by free radical-induced oxidative stress such as cancer and cardiovascular and neurodegenerative diseases $[12,13]$.

Various studies have reported previously that reactive oxygen species (ROS) are highly reactive and cause damage to protein lipids, enzymes, and DNA [14]. In this context, the use of plants and herbs in food, pharmaceutical, and cosmetic industries as a source of natural antioxidant and biologically active compounds $[15,16]$ has attracted a great deal of scientific interest. In addition, Pietta [17] reported that the antioxidant effect of plant products is mainly attributed to phenolic compounds.

In the food industry, a large spectrum of microorganism leads to food spoilage. Therefore, preservation of food material from degradation mainly by oxidation processes and microorganism activity during production, storage, and marketing is an important stage. Also, Friedman et al. [18] reported the increase of some pathogens' resistance to synthetic antibiotics which are also uncomfortable to patients due to their adverse drug reactions.

That is why the use of plants and herbs as a source of natural products has attracted the interest of many researchers. They have been screened for their potential uses as alternative remedies for the treatment of many infections, as an antioxidant, and also as a natural food preservative $[19,20]$.

Many authors have reported composition and antioxidant and antibacterial proprieties of $A$. absinthium L. essential oil and extracts. Wright [21] has reported that wormwood stimulant propriety is caused by bitter substances as artabsin (sesquiterpene lactone) and absinthin (dimer of sesquiterpene lactone) present in plant extracts. In fact, Iranian wormwood essential oil was characterized by the predominance of $\beta$-pinene and $\beta$-thujone [22]. In the same context, essential oil of A. absinthium L. collected from Morocco is essentially represented mainly by $\alpha$-thujone (39.69\%), sabinyl acetate (10.96\%), and $\beta$-thujone (7.25\%) [23]. Furthermore, Martín et al. [24] showed that the major compounds of wormwood found in the SFE extracts as well as in the hydrodistilled essential oils were Z-epoxyocimene, chrysanthenol, and chrysanthenyl acetate.

To the best of our knowledge, there are no reports dealing with chemotype A. absinthium L. essential oil in Tunisia. In our investigation, we have studied essential oil and methanolic extracts composition of wild population of wormwood cultivated in Tunisia and harvested from four distinct regions (Jérissa, Bou Salem, Boukornine, and Kairouan). Furthermore, we have evaluated their antioxidant, antibacterial, and antifungal activities. The purpose of this study was to underline the variability of wormwood essential oil and methanolic extracts and their biological activities as affected by the collection site.

\section{Material and Methods}

2.1. Chemicals. All solvents used in the experiments (diethyl ether, acetonitrile, and water of high-performance liquid chromatography (HPLC) grade and ethanol, methanol, and ethyl acetate of analytical grade) were purchased from Merck (Darmstadt, Germany). Sodium hydroxide $(\mathrm{NaOH})$, sodium phosphate $\left(\mathrm{Na}_{2} \mathrm{HPO}_{4}\right)$, sodium monobasic phosphate anhydrous $\left(\mathrm{NaH}_{2} \mathrm{PO}_{4} \mathrm{H}_{2} \mathrm{O}\right)$, sodium carbonate $\left(\mathrm{Na}_{2} \mathrm{CO}_{3}\right)$, sodium nitrite $\mathrm{NaNO}_{2}$, butylated hydroxytoluene (BHT), $\beta$-carotene, linoleic acid, ethylenediaminetetraacetic acid (EDTA), 3-(2-pyridyl)-5,6-bis(4-phenyl-sulphonic acid)-1,2,4-triazine (ferrozine), iron(II) chloride tetrahydrate $\left(\mathrm{FeCl}_{2} \cdot 4 \mathrm{H}_{2} \mathrm{O}\right)$, iron(II) chloride $\left(\mathrm{FeCl}_{2}\right)$, iron(III) chloride $\left(\mathrm{FeCl}_{3}\right)$, 1,1-diphenyl-2-picrylhydrazyl (DPPH), polyvinylpolypyrrolidone Folin-Ciocalteu reagent, potassium ferricyanide $\left(\mathrm{K}_{3} \mathrm{Fe}(\mathrm{CN})_{6}\right)$, aluminium chloride $\left(\mathrm{AlCl}_{3}\right)$, homologous series of $\mathrm{C}_{6}-\mathrm{C}_{17} \mathrm{n}$-alkanes, and high-purity standards of essential oil were purchased from Sigma-Aldrich (Steinheim, Germany). Hydrochloric acid ( $\mathrm{HCl}$ ) (36$38 \%)$ and potassium hydroxide $(\mathrm{KOH})$ were provided by J. T. Baker (Deventer, Netherlands). Trifluoroacetic acid (TFA) (99.9\%) was purchased from ROMIL Ltd. (Cambridge, UK). Cyanidin 3-O-glucoside was purchased from Extrasynthese (Genay, France). Deionized water was used to prepare all solutions, unless otherwise indicated. These solutions were wrapped in aluminium foil and stored at $4^{\circ} \mathrm{C}$. All other chemicals used were of analytical grade.

2.2. Plant Material. A. absinthium L. aerial parts were harvested randomly at flowering stage from different Tunisian regions. The choice of these sites was dictated by the geographical differences of the species studied (Table 1). The plant material was harvested from four regions (Jérissa, Bou Salem, Boukornine, and Kairouan). The harvested aerial parts were identified by Professor Abderrazek Smaoui (Borj Cédria Biotechnology Center, Tunisia) according to the Tunisian flora and a voucher specimen was deposited at the herbarium of the Laboratory of Bioactive Substances (Biotechnology Center of Borj Cédria) under the number Aab212.13. The harvested material was freeze-dried and then ground to fine powder by an electric mill and conserved in a dessicator at room temperature $\left(25^{\circ} \mathrm{C}\right)$ in darkness for further uses.

2.3. Essential Oil Extraction. The leaves, stems, and flowers were cut into small pieces and subjected to hydrodistillation type Clevenger for $90 \mathrm{~min}$ in accordance with European Pharmacopoeia method [25]. Essential oil extractions were done in triplicate for each A. absinthium L. collection site. Yield percentage was calculated as $\mathrm{mg}$ of essential oil per $100 \mathrm{~g}$ of plant dry matter. All experiments were done in triplicate.

2.4. Gas Chromatography (GC) Analysis. Analysis of A. absinthium L. essential oil volatile compounds by gas chromatography (GC) was carried out on a Hewlett-Packard 6890 gas chromatograph (Palo Alto, CA, USA) equipped with a flame ionization detector (FID) and an electronic 
TABLE 1: Geographical and bioclimatic collection sites parameters.

\begin{tabular}{lcccc}
\hline & Longitude & Latitude & Elevation $(\mathrm{m})$ & Bioclimatic stage \\
\hline Boukornine & $9^{\circ} 47^{\prime} 56.41^{\prime \prime} \mathrm{E}$ & $36^{\circ} 42^{\prime} 25.33^{\prime \prime} \mathrm{N}$ & 70 & Superior semiarid \\
Jérissa & $8^{\circ} 34^{\prime} 52.12^{\prime \prime} \mathrm{E}$ & $35^{\circ} 54^{\prime} 38.34^{\prime \prime} \mathrm{N}$ & 647 & Superior semiarid \\
Bou Salem & $8^{\circ} 59^{\prime} 2.39^{\prime \prime} \mathrm{E}$ & $36^{\circ} 38^{\prime} 8.57^{\prime \prime} \mathrm{N}$ & 247 & Subhumid \\
Kairouan & $9^{\circ} 47^{\prime} 56.41^{\prime \prime} \mathrm{E}$ & $35^{\circ} 37^{\prime} 40.86^{\prime \prime} \mathrm{N}$ & 191 & Superior arid \\
\hline
\end{tabular}

E: east, N: north.

pressure control (EPC) injector. A polar polyethylene glycol (PEG) HP-INNOWax and a 5\% diphenyl and 95\% dimethylpolysiloxane apolar HP-5 capillary columns (30 $\mathrm{m} \times$ $0.25 \mathrm{~mm}, 0.25 \mathrm{~mm}$ film thickness; Hewlett-Packard, CA, USA) were used. The flow of the carrier gas $\left(\mathrm{N}_{2}\right)$ was $1.6 \mathrm{~mL} / \mathrm{min}$. The split ratio was $60: 1$. The analysis was performed using the following temperature program: oven temperature kept isothermally at $35^{\circ} \mathrm{C}$ for $10 \mathrm{~min}$, increased from 35 to $205^{\circ} \mathrm{C}$ at the rate of $3^{\circ} \mathrm{C} / \mathrm{min}$, and kept isothermally at $205^{\circ} \mathrm{C}$ for $10 \mathrm{~min}$. Injector and detector temperatures were held, at 250 and $300^{\circ} \mathrm{C}$, respectively. The individual peaks were identified by retention times and retention indices (relative to $\mathrm{C}_{6}-\mathrm{C}_{22}$ n-alkanes), compared with those of known compounds. Percentage composition of essential oils was computed from GC-FID peak areas without correction factor.

2.5. Gas Chromatography-Mass Spectrometry (GC/MS) Analysis. Volatile compounds analysis by GC/MS was performed on a gas chromatograph HP 5890 (II) interfaced with a HP 5972 mass spectrometer (Palo Alto, CA, USA) with electron impact ionization $(70 \mathrm{eV})$. A HP-5 MS capillary column $(30 \mathrm{~m} \times 0.25 \mathrm{~mm}$, coated with $5 \%$ phenyl methyl silicone and 95\% dimethylpolysiloxane, $0.25 \mathrm{~mm}$ film thickness; HewlettPackard, CA, USA) was used. The column temperature was programmed to rise from 50 to $240^{\circ} \mathrm{C}$ at a rate of $5^{\circ} \mathrm{C} / \mathrm{min}$. The carrier gas was helium with a flow rate of $1.2 \mathrm{~mL} / \mathrm{min}$; split ratio was $60: 1$. Scan time and mass range were $1 \mathrm{~s}$ and $40-300 \mathrm{~m} / \mathrm{z}$, respectively.

2.6. Preparation of Plant Extracts. Sample extracts were obtained by stirring $1 \mathrm{~g}$ of dry aerial parts (leaves, stems, and flowers) powder with $10 \mathrm{~mL}$ of methanol according to the method of Mau et al. [26]. Obtained extracts were kept for $24 \mathrm{~h}$ at $+4^{\circ} \mathrm{C}$, filtered through a Whatman number 4 filter paper and freed of solvent under reduced pressure at $45^{\circ} \mathrm{C}$, using a rotary evaporator, and then lyophilized. The dried crude concentrated extracts were stored at $-20^{\circ} \mathrm{C}$, until used for analyses.

2.7. Total Phenolic Content. The total phenolic content was assayed using the Folin-Ciocalteu reagent, following Singleton's method, slightly modified by Dewanto et al. [27]. An aliquot $(0.125 \mathrm{~mL})$ of a suitable diluted methanol sample was added to $0.5 \mathrm{~mL}$ of deionized water and $0.125 \mathrm{~mL}$ of the Folin-Ciocalteu reagent. The mixture was shaken and allowed to stand for $6 \mathrm{~min}$, before adding $1.25 \mathrm{~mL}$ of $7 \%$ sodium carbonate $\left(\mathrm{Na}_{2} \mathrm{CO}_{3}\right)$ solution. The solution was then adjusted with deionized water to a final volume of $3 \mathrm{~mL}$ and mixed thoroughly. After incubation for $90 \mathrm{~min}$ at $23^{\circ} \mathrm{C}$, the absorbance versus prepared blank was read at $760 \mathrm{~nm}$. Total phenolic contents of leaves, stems, and flower (three replicates per treatment) were expressed as milligrams of gallic acid equivalents per gram of dry weight (mg of GAE/g of DW) through the calibration curve with gallic acid. The calibration curve range was $50-400 \mathrm{mg} / \mathrm{mL}\left(R^{2}=0.99\right)$. Triplicate measurements were taken for all samples.

2.8. Total Condensed Tannins Content. The total tannin content was measured using the modified vanillin assay described by Sun et al. [28]. A total of $3 \mathrm{~mL}$ of $4 \%$ methanol vanillin solution and $1.5 \mathrm{~mL}$ of concentrated $\mathrm{H}_{2} \mathrm{SO}_{4}$ were added to $50 \mu \mathrm{L}$ of suitably diluted sample. The mixture was kept for $15 \mathrm{~min}$, and the absorbance was measured at $500 \mathrm{~nm}$ against methanol as a blank. The amount of total condensed tannins was expressed as milligrams of $(+)$-catechin equivalent per gram of dry weight (mg of CE/g of DW) through the calibration curve with catechin. Triplicate measurements were taken for all samples.

2.9. Total Flavonoid Content. The total flavonoid content was measured according to Dewanto et al. [27]. A total of $250 \mu \mathrm{L}$ of the sample appropriately diluted was mixed with $75 \mu \mathrm{L}$ of $5 \% \mathrm{NaNO}_{2}$ (sodium nitrite). After $6 \mathrm{~min}, 150 \mu \mathrm{L}$ of $10 \%$ aluminum chloride $\left(\mathrm{AlCl}_{3}\right)$ and $500 \mu \mathrm{L}$ of $1 \mathrm{M} \mathrm{NaOH}$ were added to the mixture. Finally, the mixture was adjusted to $2.5 \mathrm{~mL}$ with distilled water. The absorbance versus prepared blank was read at $510 \mathrm{~nm}$. Total flavonoid contents of aerial parts (three replicates per treatment) were expressed as milligrams of catechin equivalents per gram of dry weight (mg of CE/g of DW) through the calibration curve with catechin. The calibration curve range was $50-188500 \mathrm{mg} / \mathrm{mL}$. Triplicate measurements were taken for all samples.

\subsection{Reversed-Phase- (RP-) HPLC Evaluation of Major} Antioxidant Compounds. Phenolic compounds analysis was carried out using an Agilent Technologies 1100 series liquid chromatograph (RP-HPLC) coupled with an UV-Vis multiwavelength detector. The separation was carried out on 250 $\times 4.6 \mathrm{~mm}, 4 \mu \mathrm{m}$ Hypersil ODS $\mathrm{C}_{18}$ reversed phase column. The mobile phase consisted of acetonitrile (solvent A) and water with $0.2 \%$ sulphuric acid (solvent B). The flow rate was kept at $0.5 \mathrm{~mL} / \mathrm{min}$. The gradient programme was as follows: $15 \%$ A/85\% B 0-12 min, 40\% A/60\% B 12-14 min, 60\% A/40\% B $14-18$ min, $80 \%$ A/20\% B $18-20$ min, $90 \%$ A/10\% B $20-$ $24 \mathrm{~min}$, and $100 \%$ A $24-28 \mathrm{~min}$. The injected volume was 
$20 \mu \mathrm{L}$ and peaks were monitored at $280 \mathrm{~nm}$. Peaks were identified by congruent retention times compared with those of authentic standards.

\subsection{Antioxidant Activities}

2.11.1. DPPH Assay. The electron donation ability of the aerial parts extracts was measured by bleaching of the purplecoloured solution of 1,1-diphenyl-2-picrylhydrazyl radical (DPPH) according to the method of Hatano [29]. One-half $\mathrm{mL}$ of $0.2 \mathrm{mM}$ DPPH methanolic solution was added to aerial parts extracts of $A$. absinthium L. $(2 \mathrm{~mL}, 10-1000 \mu \mathrm{g} / \mathrm{mL})$. After an incubation period of $30 \mathrm{~min}$ at room temperature, the absorbance was read against a blank at $517 \mathrm{~nm}$. The inhibition percentage of free radical DPPH (IP\%) was calculated as follows:

$$
\mathrm{IP} \%=\left[\frac{\left(A_{\text {blank }}-A_{\text {sample }}\right)}{A_{\text {blank }}}\right] \times 100,
$$

where $A_{\text {blank }}$ is the absorbance of the control reaction and $A_{\text {sample }}$ is the absorbance in the presence of plant extract. Extract concentration providing $50 \%$ inhibition $\left(\mathrm{IC}_{50}\right)$ was calculated from the regression equation prepared from the concentration of the extracts and the inhibition percentage. BHT was used as a positive control.

2.11.2. Reducing Power. The method of Oyaizu [30] was used to assess the reducing power of aerial parts extracts of $A$. absinthium L. These extracts $(1 \mathrm{~mL})$ were mixed with $2.5 \mathrm{~mL}$ of a $0.2 \mathrm{M}$ sodium phosphate buffer $(\mathrm{pH}=6.6)$ and $2.5 \mathrm{~mL}$ of $1 \%$ potassium ferricyanide $\left(\mathrm{K}_{3} \mathrm{Fe}(\mathrm{CN})_{6}\right)$ and incubated in a water bath at $50^{\circ} \mathrm{C}$ for $20 \mathrm{~min}$. Then, $2.5 \mathrm{~mL}$ of $10 \%$ trichloroacetic acid was added to the mixture that was centrifuged at $650 \mathrm{~g}$ for $10 \mathrm{~min}$. The supernatant $(2.5 \mathrm{~mL})$ was then mixed with $2.5 \mathrm{~mL}$ distilled water and $0.5 \mathrm{~mL}$ of $0.1 \%$ ferric chloride solution. The intensity of the blue-green color was measured at $700 \mathrm{~nm}$. The extract concentration at which the absorbance was 0.5 for the reducing power $\left(\mathrm{EC}_{50}\right)$ was obtained from the linear regression equation prepared from the concentrations of the extracts and the absorbance values. High absorbance indicates high reducing power. Ascorbic acid was used as a positive control.

2.12. Screening of Antibacterial and Antifungal Activities. Antibacterial activity was analyzed by the disc diffusion method [31] against three human pathogenic bacteria including Staphylococcus aureus 25923, Staphylococcus methicillinresistant, and Listeria monocytogenes. All bacteria were grown on $\mathrm{LB}$ plate at $30^{\circ} \mathrm{C}$ for $18-24 \mathrm{~h}$ previous inoculation onto the nutrient agar. A loop of bacteria from the agar slant stock was cultivated in nutrient broth overnight and spread with a sterile cotton swap onto Petri dishes containing $10 \mathrm{~mL}$ of API suspension medium and adjusted to the $0.5 \mathrm{McFarland}$ turbidity standards with a Densimat (bioMérieux). Sterile filter paper discs (6 $\mathrm{mm}$ in diameter) impregnated with $20 \mu \mathrm{L}$ of plant extract $(10 \mathrm{mg} / \mathrm{mL})$ were placed on the cultured plates. After $1-2 \mathrm{~h}$ at $4^{\circ} \mathrm{C}$, the treated Petri dishes were incubated at $37^{\circ} \mathrm{C}$ for $18-24 \mathrm{~h}$. The solvents, acetone/water, $2: 8$, and pure methanol without extracts served as negative controls and tetracycline was used as the positive one. The antimicrobial activity was evaluated by measuring the diameter of the growth inhibition zone around the discs. Each experiment was carried out in triplicate and the mean diameter of the inhibition zone was recorded.

The same agar-disc diffusion method was used for screening the antifungal activity of $A$. absinthium L. aerial parts extracts. Five yeast strains (Fusarium graminearum, Fusarium culmorum, Fusarium oxysporum, Sclerotinia, and Rhizoctonia solani) were first grown on Sabouraud chloramphenicol agar plate at $30^{\circ} \mathrm{C}$ for $18-24 \mathrm{~h}$. Several colonies of similar morphology of the clinical yeast were transferred into API suspension medium and adjusted to $2 \mathrm{McF}$ arland turbidity standard with a Densimat (bioMérieux). The inocula of the respective yeast were streaked on to Sabouraud chloramphenicol agar plates at $30^{\circ} \mathrm{C}$ using a sterile swab and then dried. A sterilized $6 \mathrm{~mm}$ paper disc was loaded with $20 \mu \mathrm{L}(10 \mathrm{mg} / \mathrm{mL})$ of aerial parts extract. The treated Petri dishes were placed at $4^{\circ} \mathrm{C}$ for $1-2 \mathrm{~h}$ and then incubated at $37^{\circ} \mathrm{C}$ for $18-24 \mathrm{~h}$. The inhibition of fungal growth was also evaluated by measuring the diameter of the transparent inhibition zone around each disc. Percent inhibition $(\% I)$ was calculated as $\% I=[(C-T) / C] \times$ 100 , where $C$ is the diameter of the control colonies and $T$ is the diameter of the test colonies. The average of three measurements was taken. The susceptibility of the standard was determined using a disc paper containing Nystatin.

2.13. Data Analysis. All analyses were performed in triplicate and the results are expressed as mean values \pm standard deviations (SD). The data were subjected to statistical analysis using statistical program package STATISTICA [32]. The one-way analysis of variance (ANOVA) followed by Duncan multiple range test was employed and the differences between individual mean values were deemed to be significant at $P<$ 0.05. In addition, a principal component analysis (PCA) was performed in order to discriminate between different region on the basis of their essential oils and phenolic composition.

\section{Results and Discussion}

3.1. Essential Oil Yield. The hydrodistillation extraction of $100 \mathrm{~g}$ of wormwood dry aerial parts collected from four different regions yielded a dark blue essential oil. These yields were illustrated in Figure 1. The results show that EO yield varies significantly $(P<0.05)$ according to region factor. Thereby, the optimal yield was observed at the region of Bou Salem $(1.46 \pm 0.06 \%)$ followed by the region of Kairouan $(1.12 \pm 0.08 \%)$ and Boukornine and Jérissa regions (1.10 \pm $0.04 \%$ and $1.00 \pm 0.03 \%$, resp.). Similar results were obtained by Orav et al. [33] at different European regions and the oil yields were ranged from 0.1 to $1.1 \% \mathrm{w} / \mathrm{w}$. In addition, the EO yields detected in the present study were higher than those determined by Lopes-Lutz et al. [34] in the region of the central prairies of Alberta (Canada West) that they found $(0.5 \%, w / w)$, which justifies the effect of region on the EO yield. The impact of other environmental factors on EO 


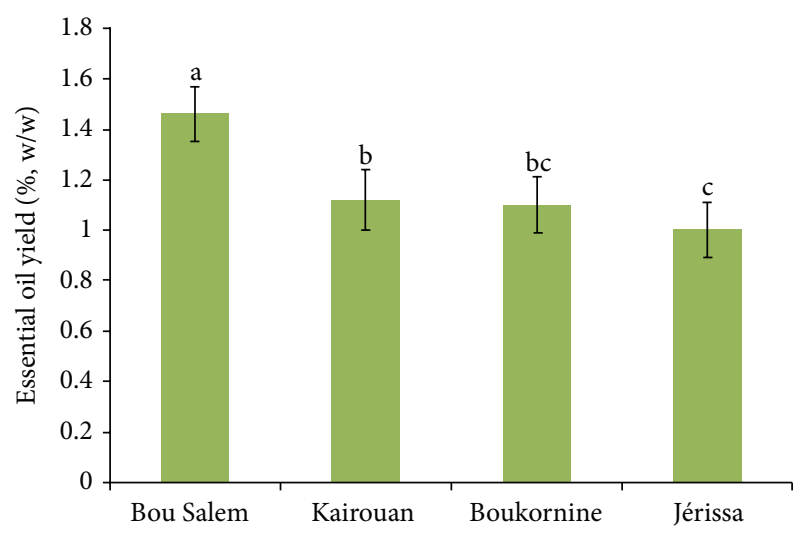

FIgURE 1: Essential oil yield of the aerial parts of $A$. absinthium L. collected from four Tunisian regions. Values with different superscripts $(\mathrm{a}-\mathrm{c})$ are significantly different at $P<0.05$.

yield was also described by Msaada et al. [35] and Msaada et al. [36, 37]. In addition, seasonal and regional variations were observed in the EO yield of coriander [38]. The same authors also reported the effect of extraction techniques on the essential oils yield and composition [39].

3.2. Variability of Chemical Composition of EO. The hydrodistillation of wormwood aerial parts collected from four different Tunisian regions provides an EO with blueblack color. This latter was due to the predominance of chamazulene component which gives the oil with a high organoleptic quality [33]. The results of chromatographic analysis by gas chromatography (GC/FID) and by coupling gas chromatography to mass spectrometry (GC/MS) are presented in Table 2.

Essential oils analyzed are divided into eight classes based on their chemical functional groups. A total of 56 compounds were identified representing $98.72 \pm 10.23 \%, 97.64 \% \pm 9.78$, $98.55 \pm 9.88 \%$, and $98.83 \pm 9.76 \%$ of total volatiles in the regions of Jérissa, Boukornine, Kairouan, and Bou Salem, respectively. These different identified compounds vary significantly $(P<0.05)$ from region to another and are highly $(P<0.001)$ affected by the regional factor (Table 2$)$.

The major contribution was attributed to the monoterpene hydrocarbons fraction which represents $56.02 \% \pm 6.21$, $45.31 \pm 5.31 \%, 45.73 \pm 5.22 \%$, and $62.08 \pm 7.49 \%$ of all compounds detected in Jérissa, Boukornine, Kairouan, and Bou Salem regions, respectively. The latter fraction is dominated by chamazulene where its maximum rate $(39.93 \pm 4.56 \%)$ was observed in the Jérissa region, followed by the regions of Bou Salem (34.81 $\pm 4.11 \%)$, Kairouan $(29.51 \pm 3.26 \%)$, and Boukornine $(25.30 \pm 3.12 \%)$. These results were in agreement with the literature. However, Kordali et al. [40] showed that essential oils chemical composition of wormwood collected in Turkey was dominated by chamazulene (17.8\%) followed by nuciferol butanoate $(8.2 \%)$, nuciferol propionate $(5.1 \%)$, and caryophyllene oxide (4.3\%). In this work, $\beta$-thujone, a monoterpene ketone, was detected with significant percentages: $22.09 \pm 2.12 \%$ in the region of Kairouan, up to
$6.72 \pm 0.75 \%$ in the region of Bou Salem. Meanwhile, the chemical composition of essential oils of wormwood growing in the USA shows that the $\beta$-thujone (17.5 to $42.3 \%$ ) and cissabinyl acetate (15.1 to $53.4 \%$ ) are the major compounds [41]. In agreement with our results, previous studies have shown that the rate of thujone in essential oils of wormwood is greater than 35\% [42]. In addition, in the wormwood samples collected from different European countries (Greece, Spain, Ukraine, France, and Italy), $\alpha$-thujone and $\beta$-thujone were detected as major components with percentages ranging from 4.5 to $38.7 \%$ [33].

It should be noted that the sesquiterpene fraction which is represented by $\alpha$-humulene, the $\gamma$-muurolene, the $\gamma$-curcumene, the $\alpha$-copaene, the $\beta$-selinene, the $\alpha$ bisabolene, the $\gamma$-cadinene, the germacrene $\mathrm{D}$, the $\alpha$ calacorene, caryophyllene oxide, and $\alpha$-bisabolol ranges from 8 to $14 \%$ of total volatiles. This slight variation could be explained by similar environmental and genetic factors. An earlier study showed that the rate of sesquiterpenes detected was $2.2 \%$ [34], rate lower than that found in this work. Monoterpene alcohols (linalool, lavandulol, terpinen-4-ol, $\alpha$ terpineol, nerol, sabinol trans-p-cymene-8-ol, eugenol, borneol, and geraniol) were highly affected by the region factor (Table 2).

Principal component analysis was carried out in order to determine the relationship between the different regions of plant collection on the basis of their essential oil composition. A better discrimination was revealed on the threedimensional visualization of the plotted scores. Results obtained from the PCA (Figure 2) showed the existence of one well-defined group represented by the regions Jérissa, Boukornine, and Kairouan suggesting similar compositions. The Bou Salem region was clearly distinguished from the latter group both in quality and in quantity.

In conclusion, the Artemisia absinthium L. plants collected from four Tunisian habitats biosynthesized essential oils of one chemotype, chamazulene.

\subsection{Total Polyphenols, Flavonoids, and Condensed Tannins} Contents. Total phenol assay is used as a routing assay to assess phenolic antioxidants due to its simplicity and reproducibility. Phenolic compounds have the ability to reduce Folin-Ciocalteu reagent and the reaction may be followed by measuring a change in the color of the solution from intense yellow to blue spectrophotometrically. Quantitative and qualitative changes of the antioxidant compounds with function to region effect hold great significance from both dietary and nutritional points of view, while phenolic compounds are used as alternatives to synthetic drugs and were shown to be safe for use in processed foods [43].

Phenolic quantification revealed a wide range of aerial parts' polyphenol contents as function of the region as shown in Figure 3 . The total polyphenol contents varied significantly $(P \leq 0.05)$ from one region to another and reached the maximum in the region of Kairouan $(99.89 \pm 3.30 \mathrm{mg} \mathrm{GAE} / \mathrm{g}$ DW), followed by the region of Bou Salem, Boukornine, and Jérissa where their levels were $83.70 \pm 1.31,72.05 \pm 1.83$, and $49.39 \pm 2.20 \mathrm{mg} \mathrm{GAE} / \mathrm{g}$ DM, respectively. Monica et al. [44] 
TABLE 2: ANOVA analysis, qualitative and quantitative essential oil composition (peak area $\% \pm \mathrm{SD}$ ) of A. absinthium L. aerial parts.

\begin{tabular}{|c|c|c|c|c|c|c|c|c|c|}
\hline \multirow{2}{*}{ Compound ${ }^{*}$} & \multirow{2}{*}{$\mathrm{RRI}^{\mathrm{a}}$} & \multirow{2}{*}{$\mathrm{RRI}^{\mathrm{b}}$} & \multicolumn{4}{|c|}{ Collection region } & \multirow{2}{*}{ df } & & \multirow{2}{*}{$P$} \\
\hline & & & Jérissa & Boukornine & Kairouan & Bou Salem & & & \\
\hline Tricyclene & 1014 & 927 & $1.00 \pm 0.11^{\mathrm{a}}$ & $0.02 \pm 0.00^{\mathrm{d}}$ & $0.74 \pm 0.06^{\mathrm{b}}$ & $0.23 \pm 0.03^{\mathrm{c}}$ & 3 & 9.6733 & $0.004^{* * *}$ \\
\hline$\alpha$-Thujene & 1032 & 939 & $0.05 \pm 0.01^{c}$ & $0.05 \pm 0.00^{c}$ & $3.28 \pm 0.32^{\mathrm{a}}$ & $0.23 \pm 0.02^{\mathrm{b}}$ & 3 & 10077.77 & $0.000^{* * *}$ \\
\hline$\alpha$-Pinene & 1035 & 931 & $0.10 \pm 0.01^{c}$ & $0.02 \pm 0.00^{\mathrm{b}}$ & $0.62 \pm 0.05^{\mathrm{a}}$ & $0.20 \pm 0.03^{\mathrm{b}}$ & 3 & 65.81 & $0.000^{* * *}$ \\
\hline Camphene & 1076 & 950 & $0.06 \pm 0.01^{\mathrm{c}}$ & $0.03 \pm 0.00^{\mathrm{d}}$ & $0.66 \pm 0.07^{\mathrm{a}}$ & $0.24 \pm 0.03^{\mathrm{b}}$ & 3 & 163.01 & $0.000^{* * *}$ \\
\hline$\beta$-Pinene & 1118 & 980 & $1.20 \pm 0.10^{\mathrm{a}}$ & $0.25 \pm 0.02^{\mathrm{c}}$ & $0.02 \pm 0.00^{\mathrm{d}}$ & $0.27 \pm 0.03^{\mathrm{b}}$ & 3 & 251.96 & $0.000^{* * *}$ \\
\hline Sabinene & 1132 & 976 & $0.28 \pm 0.03^{c}$ & $1.87 \pm 0.19^{\mathrm{a}}$ & $0.02 \pm 0.00^{\mathrm{d}}$ & $1.67 \pm 0.15^{\mathrm{b}}$ & 3 & 3383.83 & $0.000^{* * *}$ \\
\hline Myrcene & 1176 & 988 & $0.50 \pm 0.04^{\mathrm{b}}$ & $0.05 \pm 0.01^{c}$ & $1.52 \pm 0.14^{\mathrm{a}}$ & $0.02 \pm 0.00^{\mathrm{d}}$ & 3 & 555.19 & $0.000^{* * *}$ \\
\hline$\alpha$-Terpinene & 1188 & 1018 & $0.03 \pm 0.00^{c}$ & $0.44 \pm 0.05^{\mathrm{a}}$ & $0.08 \pm 0.01^{\mathrm{b}}$ & $0.03 \pm 0.00^{c}$ & 3 & 247.78 & $0.000^{* * *}$ \\
\hline Limonene & 1203 & 1026 & $0.10 \pm 0.01^{\mathrm{d}}$ & $0.95 \pm 0.08^{\mathrm{a}}$ & $0.14 \pm 0.01^{c}$ & $0.40 \pm 0.03^{\mathrm{b}}$ & 3 & 39.49 & $0.000^{* * *}$ \\
\hline 1,8-Cineole & 1213 & 1033 & $0.03 \pm 0.00^{c}$ & $0.03 \pm 0.00^{c}$ & $0.35 \pm 0.04^{\mathrm{a}}$ & $0.08 \pm 0.01^{\mathrm{b}}$ & 3 & 83.14 & $0.000^{* * *}$ \\
\hline$\beta$-Phellandrene & 1218 & 1031 & $0.10 \pm 0.02^{\mathrm{b}}$ & $0.04 \pm 0.00^{\mathrm{d}}$ & $0.06 \pm 0.01^{c}$ & $0.26 \pm 0.03^{\mathrm{a}}$ & 3 & 25.44 & $0.000^{* * *}$ \\
\hline$Z$ - $\beta$-Ocimene & 1246 & 1040 & $0.20 \pm 0.03^{c}$ & $1.59 \pm 0.16^{\mathrm{a}}$ & $0.26 \pm 0.03^{\mathrm{b}}$ & $0.05 \pm 0.00^{\mathrm{d}}$ & 3 & 538.84 & $0.000^{* * *}$ \\
\hline$E$ - $\beta$-Ocimene & 1266 & 1050 & $0.08 \pm 0.01^{\mathrm{d}}$ & $0.10 \pm 0.02^{c}$ & $1.40 \pm 0.16^{\mathrm{a}}$ & $0.43 \pm 0.05^{\mathrm{b}}$ & 3 & 105.86 & $0.000^{* * *}$ \\
\hline$\gamma$-Terpinene & 1267 & 1062 & $0.10 \pm 0.02^{\mathrm{b}}$ & $0.07 \pm 0.01^{c}$ & $0.18 \pm 0.02^{\mathrm{a}}$ & $0.04 \pm 0.00^{\mathrm{d}}$ & 3 & 27.18 & $0.000^{* * *}$ \\
\hline p-Cymene & 1280 & 1026 & $0.08 \pm 0.01^{c}$ & $0.12 \pm 0.01^{\mathrm{b}}$ & $0.22 \pm 0.03^{\mathrm{a}}$ & $0.04 \pm 0.00^{\mathrm{d}}$ & 3 & 44.75 & $0.000^{* * *}$ \\
\hline Terpinolene & 1290 & 1088 & $0.20 \pm 0.03^{\mathrm{b}}$ & $0.13 \pm 0.01^{c}$ & $0.12 \pm 0.01^{\mathrm{cd}}$ & $0.62 \pm 0.05^{\mathrm{a}}$ & 3 & 57.94 & $0.000^{* * *}$ \\
\hline$\beta$-Thujone & 1430 & 1089 & $17.16 \pm 1.56^{\mathrm{c}}$ & $21.02 \pm 2.32^{\mathrm{b}}$ & $22.09 \pm 2.12^{\mathrm{a}}$ & $6.72 \pm 0.75^{\mathrm{d}}$ & 3 & 590069.9 & $0.000^{* * *}$ \\
\hline$\alpha$-Thujone & 1430 & 1089 & $0.20 \pm 0.02^{\mathrm{b}}$ & $0.07 \pm 0.01^{\mathrm{c}}$ & $0.28 \pm 0.03^{\mathrm{a}}$ & $0.04 \pm 0.00^{\mathrm{d}}$ & 3 & 13.52 & $0.001^{* * *}$ \\
\hline trans-Linalool oxide & 1450 & 1088 & $0.03 \pm 0.00^{c}$ & $0.02 \pm 0.00^{\mathrm{d}}$ & $6.04 \pm 0.77^{\mathrm{a}}$ & $2.58 \pm 0.25^{\mathrm{b}}$ & 3 & 11876.62 & $0.000^{* * *}$ \\
\hline trans-Sabinene hydrate & 1474 & 1053 & $12.07 \pm 1.32^{\mathrm{c}}$ & $12.58 \pm 1.30^{\mathrm{b}}$ & $5.32 \pm 0.56^{\mathrm{d}}$ & $21.78 \pm 2.12^{\mathrm{a}}$ & 3 & 242741.2 & $0.000^{* * *}$ \\
\hline cis-Linalool oxide & 1478 & 1074 & $0.05 \pm 0.00^{c}$ & $0.13 \pm 0.01^{\mathrm{b}}$ & $0.05 \pm 0.01^{c}$ & $1.86 \pm 0.16^{\mathrm{a}}$ & 3 & 6371.93 & $0.000^{* * *}$ \\
\hline$\alpha$-Copaene & 1497 & 1379 & $0.50 \pm 0.04^{\mathrm{b}}$ & $4.07 \pm 0.44^{\mathrm{a}}$ & $0.33 \pm 0.03^{c}$ & $0.22 \pm 0.03^{\mathrm{d}}$ & 3 & 3561.91 & $0.000^{* * *}$ \\
\hline Camphor & 1532 & 1143 & $0.02 \pm 0.00^{\mathrm{d}}$ & $0.04 \pm 0.00^{c}$ & $0.15 \pm 0.01^{\mathrm{a}}$ & $0.12 \pm 0.01^{b}$ & 3 & 13.73 & $0.001^{* * *}$ \\
\hline Linalool & 1553 & 1088 & $2.00 \pm 0.23^{\mathrm{a}}$ & $0.80 \pm 0.07^{\mathrm{b}}$ & $0.09 \pm 0.01^{\mathrm{d}}$ & $0.15 \pm 0.02^{\mathrm{c}}$ & 3 & 9.32 & $0.005^{* *}$ \\
\hline cis-Sabinene hydrate & 1556 & 1082 & $0.02 \pm 0.00^{\mathrm{d}}$ & $1.82 \pm 0.15^{\mathrm{a}}$ & $1.80 \pm 0.20^{\mathrm{b}}$ & $0.80 \pm 0.07^{\mathrm{c}}$ & 3 & 441.83 & $0.000^{* * *}$ \\
\hline Linalyl acetate & 1565 & 1239 & $0.50 \pm 0.06^{\mathrm{b}}$ & $4.58 \pm 0.51^{\mathrm{a}}$ & $0.08 \pm 0.01^{\mathrm{d}}$ & $0.21 \pm 0.03^{\mathrm{c}}$ & 3 & 5308.55 & $0.000^{* * *}$ \\
\hline Bornyl acetate & 1590 & 1270 & $1.10 \pm 0.10^{\mathrm{a}}$ & $0.04 \pm 0.00^{c}$ & $0.36 \pm 0.04^{\mathrm{b}}$ & $0.02 \pm 0.00^{\mathrm{d}}$ & 3 & 268.07 & $0.000^{* * *}$ \\
\hline Terpinene-4-ol & 1611 & 1176 & $3.00 \pm 0.41^{\mathrm{a}}$ & $0.15 \pm 0.01^{c}$ & $0.05 \pm 0.00^{\mathrm{d}}$ & $1.10 \pm 0.12^{\mathrm{b}}$ & 3 & 22.16 & $0.000^{* * *}$ \\
\hline cis-Dihydrocarvone & 1645 & 1193 & $0.48 \pm 0.05^{\mathrm{b}}$ & $0.94 \pm 0.08^{\mathrm{a}}$ & $0.11 \pm 0.01^{c}$ & $0.03 \pm 0.00^{\mathrm{d}}$ & 3 & 942.9 & $0.000^{* * *}$ \\
\hline cis-Verbenol & 1654 & 1132 & $2.34 \pm 0.24^{\mathrm{b}}$ & $0.02 \pm 0.00^{\mathrm{d}}$ & $0.31 \pm 0.04^{\mathrm{c}}$ & $3.57 \pm 0.44^{\mathrm{a}}$ & 3 & 15604.73 & $0.000^{* * *}$ \\
\hline Sabinyl acetate & 1658 & 1291 & $0.29 \pm 0.03^{b}$ & $5.01 \pm 0.45^{\mathrm{a}}$ & $0.11 \pm 0.01^{\mathrm{c}}$ & $0.08 \pm 0.01^{\mathrm{d}}$ & 3 & 100958.1 & $0.000^{* * *}$ \\
\hline trans-Sabinol & 1666 & 1120 & $0.29 \pm 0.03^{\mathrm{b}}$ & $0.04 \pm 0.00^{\mathrm{d}}$ & $0.06 \pm 0.01^{c}$ & $0.99 \pm 0.08^{\mathrm{a}}$ & 3 & 1582.13 & $0.000^{* * *}$ \\
\hline Lavandulol & 1677 & 1150 & $2.71 \pm 0.31^{c}$ & $0.28 \pm 0.03^{\mathrm{d}}$ & $3.61 \pm 0.34^{\mathrm{b}}$ & $5.54 \pm 0.61^{\mathrm{a}}$ & 3 & 26002.36 & $0.000^{* * *}$ \\
\hline$\alpha$-Humulene & 1687 & 1454 & $0.08 \pm 0.01^{\mathrm{b}}$ & $0.62 \pm 0.05^{\mathrm{a}}$ & $0.03 \pm 0.00^{c}$ & $0.01 \pm 0.00^{\mathrm{d}}$ & 3 & 1699.33 & $0.000^{* * *}$ \\
\hline Neral & 1694 & 1240 & $0.01 \pm 0.00^{\mathrm{d}}$ & $0.26 \pm 0.03^{c}$ & $2.68 \pm 0.27^{\mathrm{a}}$ & $0.28 \pm 0.03^{\mathrm{b}}$ & 3 & 11106.53 & $0.000^{* * *}$ \\
\hline$\gamma$-Muurolene & 1692 & 1474 & $0.28 \pm 0.03^{\mathrm{b}}$ & $1.09 \pm 0.11^{\mathrm{a}}$ & $0.15 \pm 0.02^{\mathrm{c}}$ & $0.05 \pm 0.00^{\mathrm{d}}$ & 3 & 871.32 & $0.000^{* * *}$ \\
\hline$\gamma$-Curcumene & 1704 & 1475 & $1.00 \pm 0.12^{\mathrm{c}}$ & $2.93 \pm 0.32^{\mathrm{a}}$ & $0.57 \pm 0.06^{\mathrm{d}}$ & $1.95 \pm 0.22^{b}$ & 3 & 52.19 & $0.000^{* * *}$ \\
\hline$\alpha$-Terpinyl acetate & 1705 & 1344 & $0.17 \pm 0.01^{\mathrm{a}}$ & $\operatorname{tr}$ & $0.14 \pm 0.01^{\mathrm{b}}$ & $0.03 \pm 0.00^{c}$ & 3 & 91.11 & $0.000^{* * *}$ \\
\hline$\alpha$-Terpineol & 1706 & 1189 & $0.19 \pm 0.02^{\mathrm{b}}$ & $0.14 \pm 0.01^{\mathrm{c}}$ & $0.05 \pm 0.01^{\mathrm{d}}$ & $0.38 \pm 0.04^{\mathrm{a}}$ & 3 & 93.12 & $0.000^{* * *}$ \\
\hline Borneol & 1719 & 1165 & $0.52 \pm 0.06^{\mathrm{a}}$ & $0.46 \pm 0.05^{\mathrm{b}}$ & $0.23 \pm 0.03^{c}$ & $\operatorname{tr}$ & 3 & 397.35 & $0.000^{* * *}$ \\
\hline Germacrene D & 1726 & 1480 & $0.04 \pm 0.00^{\mathrm{d}}$ & $0.10 \pm 0.01^{c}$ & $1.58 \pm 0.17^{\mathrm{a}}$ & $0.52 \pm 0.06^{\mathrm{b}}$ & 3 & 1647.56 & $0.000^{* * *}$ \\
\hline Neryl acetate & 1732 & 1356 & $0.20 \pm 0.02^{\mathrm{c}}$ & $0.26 \pm 0.03^{\mathrm{b}}$ & $0.03 \pm 0.00^{\mathrm{d}}$ & $0.51 \pm 0.06^{\mathrm{a}}$ & 3 & 42.73 & $0.000^{* * *}$ \\
\hline$\beta$-Selinene & 1742 & 1486 & $4.72 \pm 0.51^{\mathrm{c}}$ & $4.50 \pm 0.50^{\mathrm{d}}$ & $5.29 \pm 0.62^{\mathrm{b}}$ & $6.67 \pm 0.74^{\mathrm{a}}$ & 3 & 45.48 & $0.000^{* * *}$ \\
\hline$\alpha$-Bisabolene & 1746 & 1494 & $0.88 \pm 0.09^{b}$ & $0.11 \pm 0.01^{c}$ & $1.25 \pm 0.15^{\mathrm{a}}$ & $0.02 \pm 0.00^{\mathrm{d}}$ & 3 & 15.32 & $0.001^{* * *}$ \\
\hline Carvone & 1751 & 1242 & $2.00 \pm 0.31^{\mathrm{a}}$ & $0.14 \pm 0.01^{\mathrm{c}}$ & $0.46 \pm 0.05^{\mathrm{b}}$ & $0.05 \pm 0.00^{\mathrm{d}}$ & 3 & 9.88 & $0.004^{* *}$ \\
\hline Geranyl acetate & 1765 & 1383 & $0.08 \pm 0.01^{b}$ & $0.61 \pm 0.07^{\mathrm{a}}$ & $0.03 \pm 0.00^{c}$ & $0.02 \pm 0.00^{\mathrm{d}}$ & 3 & 2429 & $0.000^{* * *}$ \\
\hline$\gamma$-Cadinene & 1776 & 1526 & $0.40 \pm 0.05^{\mathrm{c}}$ & $1.12 \pm 0.15^{\mathrm{b}}$ & $1.27 \pm 0.13^{\mathrm{a}}$ & $0.05 \pm 0.00^{\mathrm{d}}$ & 3 & 98.38 & $0.000^{* * *}$ \\
\hline Nerol & 1797 & 1228 & $0.10 \pm 0.01^{c}$ & $0.11 \pm 0.01^{c}$ & $0.33 \pm 0.04^{\mathrm{b}}$ & $1.93 \pm 0.31^{\mathrm{a}}$ & 3 & 2118.79 & $0.000^{* * *}$ \\
\hline Geraniol & 1857 & 1255 & $0.65 \pm 0.07^{\mathrm{a}}$ & $0.03 \pm 0.00^{\mathrm{d}}$ & $0.04 \pm 0.00^{c}$ & $0.20 \pm 0.02^{\mathrm{b}}$ & 3 & 77.96 & $0.000^{* * *}$ \\
\hline p-Cymene-8-ol & 1864 & 1183 & $\operatorname{tr}$ & $0.96 \pm 0.08^{\mathrm{b}}$ & $3.70 \pm 0.41^{\mathrm{a}}$ & $\operatorname{tr}$ & 3 & 3636.71 & $0.000^{* * *}$ \\
\hline
\end{tabular}


TABLE 2: Continued.

\begin{tabular}{|c|c|c|c|c|c|c|c|c|c|}
\hline \multirow{2}{*}{ Compound ${ }^{*}$} & \multirow{2}{*}{$\mathrm{RRI}^{\mathrm{a}}$} & \multirow{2}{*}{$\mathrm{RRI}^{\mathrm{b}}$} & \multicolumn{4}{|c|}{ Collection region } & \multirow{2}{*}{ df } & \multirow{2}{*}{$F$} & \multirow{2}{*}{$P$} \\
\hline & & & Jérissa & Boukornine & Kairouan & Bou Salem & & & \\
\hline$\alpha$-Calacorene & 1920 & 1527 & $0.11 \pm 0.01^{\mathrm{d}}$ & $0.16 \pm 0.02^{b}$ & $0.12 \pm 0.01^{c}$ & $0.52 \pm 0.06^{\mathrm{a}}$ & 3 & 355.3 & $0.000^{* * *}$ \\
\hline Caryophyllene oxide & 2008 & 1578 & $0.05 \pm 0.00^{\mathrm{b}}$ & $0.06 \pm 0.01^{\mathrm{a}}$ & $0.06 \pm 0.00^{\mathrm{a}}$ & $\operatorname{tr}$ & 3 & 16.5 & $0.000^{* * *}$ \\
\hline cis-Nerolidol & 2050 & 1553 & $0.27 \pm 0.03^{\mathrm{a}}$ & $0.06 \pm 0.01^{c}$ & $0.07 \pm 0.01^{\mathrm{b}}$ & $0.01 \pm 0.00^{\mathrm{d}}$ & 3 & 92.88 & $0.000^{* * *}$ \\
\hline Eugenol & 2192 & 1356 & $0.15 \pm 0.02^{\mathrm{d}}$ & $1.24 \pm 0.14^{\mathrm{a}}$ & $0.32 \pm 0.04^{\mathrm{b}}$ & $0.20 \pm 0.03^{c}$ & 3 & 218.06 & $0.000^{* * *}$ \\
\hline$\alpha$-Bisabolol & 2232 & 1673 & $0.03 \pm 0.00^{\mathrm{b}}$ & $0.02 \pm 0.00^{\mathrm{c}}$ & $0.15 \pm 0.02^{\mathrm{a}}$ & $0.01 \pm 0.00^{\mathrm{d}}$ & 3 & 19.07 & $0.000^{* * *}$ \\
\hline Chamazulene & 2430 & 1719 & $39.93 \pm 4.56^{\mathrm{a}}$ & $25.30 \pm 3.12^{\mathrm{d}}$ & $29.51 \pm 3.26^{\mathrm{c}}$ & $34.81 \pm 4.11^{\mathrm{b}}$ & 3 & 5324.71 & $0.000^{* * *}$ \\
\hline \multicolumn{10}{|c|}{ Chemical classes } \\
\hline \multicolumn{3}{|c|}{ Monoterpene hydrocarbons } & $56.02 \pm 6.21^{\mathrm{b}}$ & $45.31 \pm 5.31^{\mathrm{d}}$ & $45.73 \pm 5.22^{c}$ & $62.08 \pm 7.49^{\mathrm{a}}$ & 3 & 26322.56 & $0.000^{* * *}$ \\
\hline \multicolumn{3}{|c|}{ Aromatic hydrocarbons } & $0.08 \pm 0.01^{c}$ & $0.12 \pm 0.01^{\mathrm{b}}$ & $0.22 \pm 0.03^{\mathrm{a}}$ & $0.04 \pm 0.00^{\mathrm{d}}$ & 3 & 9563.42 & $0.000^{* * *}$ \\
\hline \multicolumn{3}{|c|}{ Monoterpene alcohols } & $12.22 \pm 1.33^{\mathrm{b}}$ & $4.29 \pm 0.52^{\mathrm{d}}$ & $8.86 \pm 0.96^{\mathrm{c}}$ & $14.07 \pm 1.67^{\mathrm{a}}$ & 3 & 912.67 & $0.000^{* * *}$ \\
\hline \multicolumn{3}{|c|}{ Monoterpene esters } & $2.34 \pm 0.31^{\mathrm{b}}$ & $10.05 \pm 1.23^{\mathrm{a}}$ & $0.75 \pm 0.08^{\mathrm{d}}$ & $0.87 \pm 0.09^{c}$ & 3 & 567.01 & $0.000^{* * *}$ \\
\hline \multicolumn{3}{|c|}{ Monoterpene ketones } & $19.86 \pm 2.13^{\mathrm{c}}$ & $22.21 \pm 2.11^{\mathrm{b}}$ & $23.09 \pm 3.10^{\mathrm{a}}$ & $6.96 \pm 7.41^{\mathrm{d}}$ & 3 & 152.73 & $0.000^{* * *}$ \\
\hline \multicolumn{3}{|c|}{ Monoterpene aldehydes } & $0.01 \pm 0.00^{\mathrm{d}}$ & $0.26 \pm 0.03^{\mathrm{c}}$ & $2.68 \pm 2.45^{\mathrm{a}}$ & $0.28 \pm 0.03^{\mathrm{b}}$ & 3 & 4360.02 & $0.000^{* * *}$ \\
\hline \multicolumn{3}{|c|}{ Monoterpene ethers } & $0.11 \pm 0.01^{\mathrm{d}}$ & $0.18 \pm 0.02^{\mathrm{c}}$ & $6.44 \pm 0.77^{\mathrm{a}}$ & $4.52 \pm 0.51^{\mathrm{b}}$ & 3 & 4265.16 & $0.000^{* * *}$ \\
\hline \multicolumn{3}{|c|}{ Sesquiterpenes } & $8.09 \pm 0.99^{\mathrm{d}}$ & $14.78 \pm 1.66^{\mathrm{a}}$ & $10.80 \pm 1.45^{\mathrm{b}}$ & $10.02 \pm 1.78^{\mathrm{c}}$ & 3 & 1235.94 & $0.000^{* * *}$ \\
\hline \multicolumn{3}{|c|}{ Total identified } & $98.72 \pm 10.23^{b}$ & $97.64 \pm 9.78^{\mathrm{d}}$ & $98.55 \pm 9.88^{\mathrm{c}}$ & $98.83 \pm 9.76^{\mathrm{a}}$ & 3 & 4581.23 & $0.000^{* * *}$ \\
\hline
\end{tabular}

RRI: relative retention index; a: HP-INNOWax, b: HP-5. * Compounds in order of elution on HP-INNOWax; values of volatile essential oil percentages are the average three determinations $(n=3)$. These values with different letters $(\mathrm{a}-\mathrm{d})$ are significantly different at $P<0.05$. nd: not detected. NS: not significant. ${ }^{* *} P<$ $0.01{ }^{* * *} P<0.001$.

df: degree of freedom, $F$ : Fisher value, and $P$ : probability.

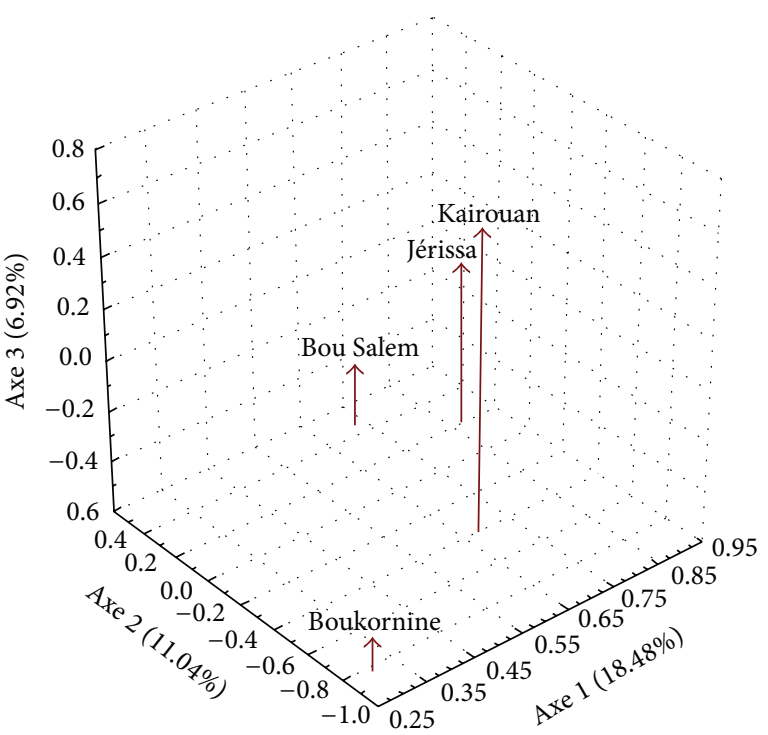

FIGURE 2: Relative position of the regions of plant collection based on their essential oils composition (Table 2) in the space defined by the three principal components.

showed that total polyphenol content of wormwood aerial parts collected in Romania was $98.20 \mathrm{mg} / \mathrm{g}$ DW. In addition, Ebrahimzadeh et al. [45] reported that the total polyphenol content of Iranian wormwood aerial parts was $194 \pm 9.7 \mathrm{mg}$ EAG/g of extract which was significantly of greater value in comparison with our results. However, a lower content in total polyphenols (9.79 mg EAG/g extract) content was determined by Sengul et al. [46]. Other herbs with high levels of phenolics were Polygonum aviculare (11.2 mg GAE/100 g DW) and Valeriana officinalis (11.1 mg GAE/100 g DW) [47]. In general, phenolic compounds are known for their role in the prevention of some diseases due to their richness in antioxidants and their antiradical effect, protecting cellular components against damage induced by free radicals. Due to the diversity of their chemical structures, they are likely to have very different antioxidant capacity [48]. Polyphenolic compounds are commonly found in both edible and inedible plants, and they have been reported to have multiple biological effects, including antioxidant activity [47]. The basic flavonoids structure is the flavan nucleus, which consists of 15 carbon atoms arranged in three rings $\left(C_{6}-C_{3}-C_{6}\right)$, labeled A, B, and C. Various classes of flavonoid differ in the level of oxidation and saturation of ring $\mathrm{C}$, while individual compounds within a class differ in the substitution pattern of rings $\mathrm{A}$ and $\mathrm{B}$. The differences in the structure and substitution will influence the phenoxyl radical stability and thereby the antioxidant properties of the flavonoids [49].

As for total polyphenols, total flavonoids differ significantly $(P \leq 0.05)$ depending on the region, but with a maximum in Kairouan region (126.40 $\pm 2.32 \mathrm{mg} \mathrm{CE} / \mathrm{g} \mathrm{DW})$ (Figure 3).

Our results are in agreement with those reported by Wojdyło et al. [47] in that the most common flavonoids are mainly distributed in Compositae family. On the other hand, A. absinthium L. aerial parts have been reported to contain flavonoids [50-52], thymol, and carvacrol as well as other phenolic compounds [53]. These pharmacophores have been shown to possess potent antioxidant and free radical scavenging activity [54]. In the present study, high levels of phenolic and flavonoid contents were estimated. For total 


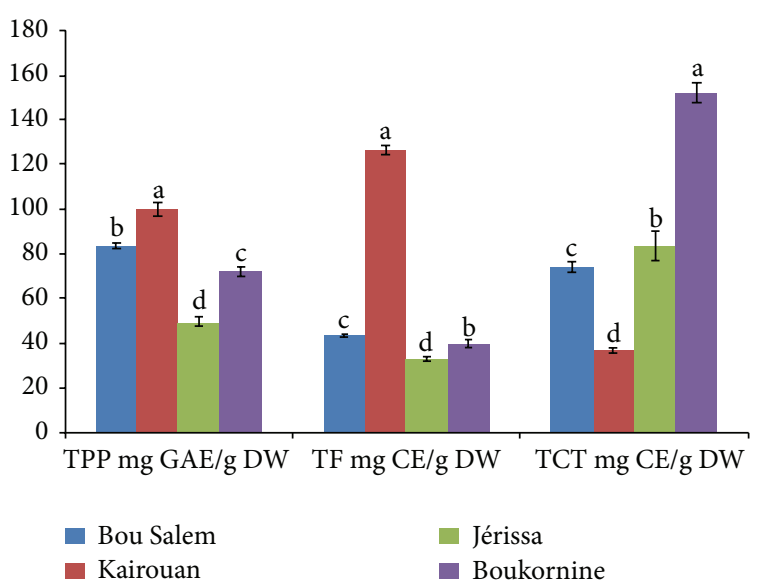

FIgUre 3: Total polyphenols (TPP), total flavonoids (TF), and total condensed tannin (TCT) contents of different regions of $A$. absinthium L. aerial parts. GAE: gallic acid equivalents; CE: catechin equivalents. The letters $(a-d)$ indicate significant differences $(P<$ $0.05)$.

condensed tannins, the maximum level was detected in the region Boukornine $(152.35 \pm 4.59 \mathrm{mg} \mathrm{CE} / \mathrm{g} \mathrm{DW})$ followed by Jérissa $(83.50 \pm 6.69 \mathrm{mg}$ CE/g DW), Bou Salem (73.94 \pm $2.19 \mathrm{mg}$ CE/g DW), and Kairouan (37.19 $\pm 1.16 \mathrm{mg}$ CE/g DW) regions (Figure 3).

3.4. Individual Phenolic Compounds. For a clear understanding of the regional effect on metabolic changes especially on phenolics, it is necessary to investigate the profiles of individual phenolic compounds in A. absinthium L. Hence, changes of these phenolic compounds were different at four Tunisian regions (Table 3 ). The obtained results show that all the identified compounds were highly significant $(P<0.001)$ by the region effect. Phenolic acids-tannic, gallic, hemihydrate chlorogenic, caffeic, vanillic, syringic, ferulic, p-coumaric, rosmarinic, and trans-cinnamic acids-represent the major fraction of the polyphenols analyzed in regions of Bou Salem (34.96 $\pm 3.56 \%)$, Kairouan ( $45.57 \pm 5.23 \%$ ), and Jérissa $(58.33 \pm 6.21 \%)$, while the flavones dominated at Boukornine region $(38.61 \pm 4.13 \%)$. In the regions of Bou Salem, Kairouan, and Boukornine, the flavone was the predominant fraction $(19.44 \pm 2.36 \%, 11.88 \pm 2.11 \%$, and $32.47 \pm 4.23 \%$, resp.), while, in the region of Jérissa, tannic acid was the predominant compound $(37.92 \pm 4.02 \%)$. The quantification of total polyphenols of wormwood aerial parts by the Folin-Ciocalteu method gave different results in all studied regions. In the region of Bou Salem, total polyphenols measured by Folin-Ciocalteu method were estimated to be $83.7 \mathrm{mg} \mathrm{GAE} / \mathrm{g}$ DW and $28.03 \pm 3.12 \mathrm{mg} / \mathrm{g}$ GAE DW by HPLC, in Kairouan were 99; $89 \mathrm{mg}$ GAE/g DW by Folin-Ciocalteu and $15.91 \pm 1.65 \mathrm{mg}$ GAE/g by HPLC, in Boukornine were $72.05 \mathrm{mg}$ GAE/g DW by FolinCiocalteu and $48.23 \pm 5.21 \mathrm{mg}$ GAE/g DM by HPLC, and in Jérissa were $49.39 \mathrm{mg}$ GAE/g DW by Folin-Ciocalteu and $88.08 \pm 7.59 \mathrm{mg} \mathrm{GAE} / \mathrm{g}$ DW by HPLC. These variations in the quantification showed a significant difference depending on

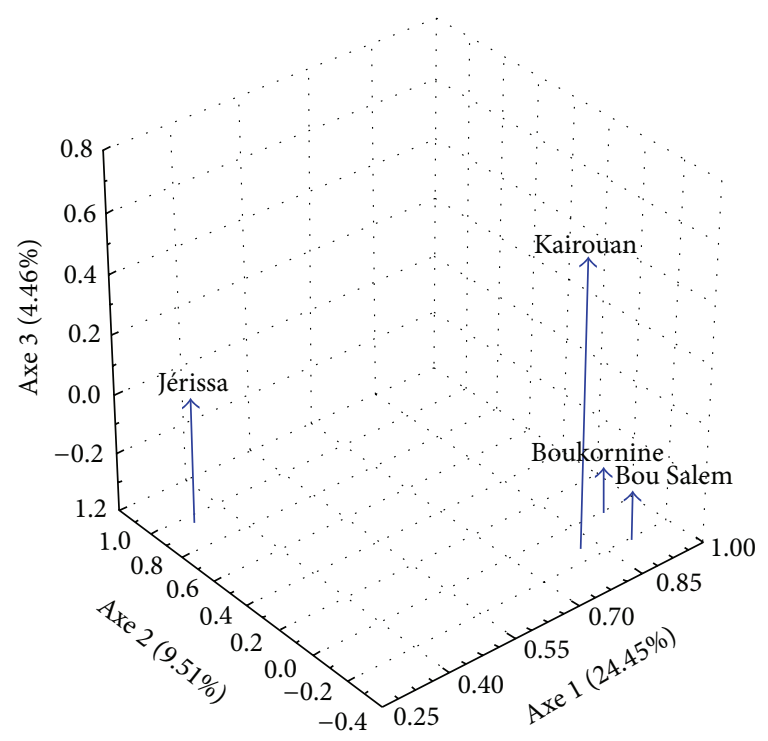

FIGURE 4: Principal component analysis of different regions based on the phenolic composition of A. absinthium L. (Table 3 ).

the method used. An earlier study showed that the analysis by liquid chromatography (HPLC) revealed the presence of other flavonoid glycosides (isoquercitrin, quercetin-3-O$\beta$-D-glucoside, quercetin-3-O-rhamnoglucoside, isorhamnetin-3-O-rhamnoglucoside, and isorhamnetin-3-glucoside) [50], which are characterized by important antioxidant activity. Gallic acid, widely used as an additive to prevent food spoilage, is renowned for its anticarcinogenic, antiinflammatory, and antimutagenic activities [55].

A principal component analysis (PCA) was performed in order to discriminate between different regions of collecting of absinthe based on the phenolic composition. This analysis revealed the existence of one group composed by Boukornine, Kairouan, and Bou Salem regions. But Jérissa is clearly distinct from this group (Figure 4).

A. absinthium L. can be considered a good source of naturally occurring antioxidant compounds, which have an application in food industry, due to its phenolic composition.

3.5. DPPH Test. As indicated in Table 4, the methanol extracts are highly influenced by the regional effect (antiradical activity was region-dependent). Methanolic extract of Bou Salem region shows the highest antioxidant activity $(9.38 \pm$ $0.82 \mathrm{mg} / \mathrm{mL}$ ) which was stronger than that of the positive control: BHT $(10.77 \pm 2.98 \mu \mathrm{g} / \mathrm{mL})$. The lower activity was detected in the region of Boukornine $(44.26 \pm 1.92 \mathrm{mg} / \mathrm{mL})$. Mahmoudi et al. [9] have reported an antiradical of wormwood aerial parts activity with an $\mathrm{IC}_{50}$ of $612 \pm 30.6 \mu \mathrm{g} / \mathrm{mL}$; this value was lower than our results. Meanwhile, Sengul et al. [46] showed that the antiradical activity of the methanol extracts of the aerial parts of wormwood collected in Turkey was $71.78 \%$ as compared to the positive control $(\mathrm{BHA}=$ $200 \mathrm{mg} / \mathrm{L}$ measuring 93.21\%). Different results were found by Wojdyło et al. [47], who reported a highly significant positive correlation $(R=0.8352, P<0.05)$ between 


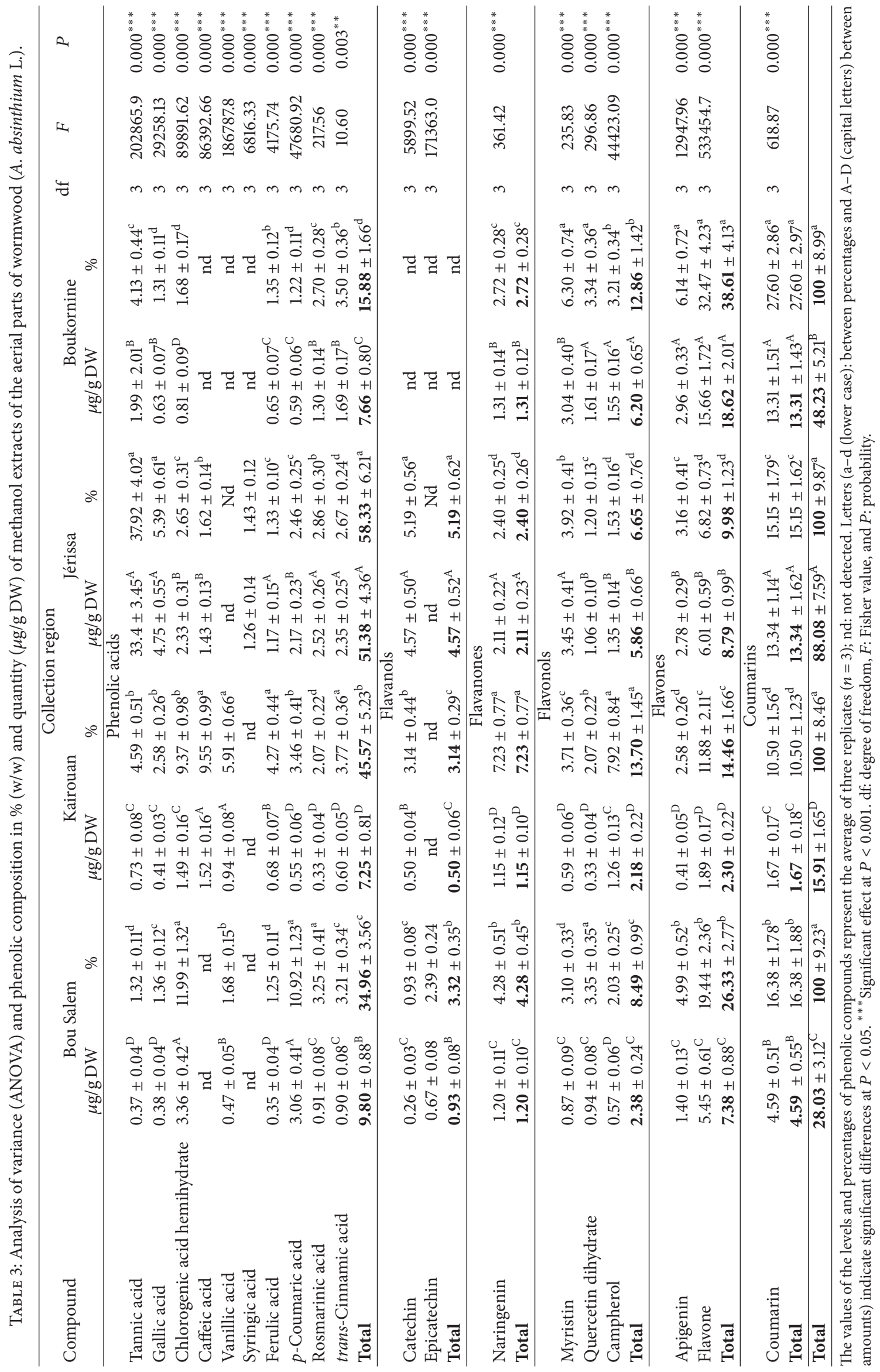


TABLE 4: DPPH test $\left(\mathrm{IC}_{50} \mu \mathrm{g} / \mathrm{mL}\right)$ and reducing power $\left(\mathrm{EC}_{50} \mu \mathrm{g} / \mathrm{mL}\right)$ of methanol extracts of wormwood aerial parts.

\begin{tabular}{|c|c|c|c|c|c|c|c|c|c|}
\hline & Bou Salem & Kairouan & Jérissa & Boukornine & BHT & Ascorbic acid & $\mathrm{df}$ & $F$ & $P$ \\
\hline $\mathrm{DPPH}\left(\mathrm{IC}_{50} \mu \mathrm{g} / \mathrm{mL}\right)$ & $9.38 \pm 0.82^{\mathrm{d}}$ & $18.99 \pm 0.38^{c}$ & $31.74 \pm 1.23^{\mathrm{b}}$ & $44.26 \pm 1.92^{\mathrm{a}}$ & $10.77 \pm 2.98$ & & 3 & 56.46 & $0.000^{* * *}$ \\
\hline $\begin{array}{l}\text { Reducing power } \\
\left(\mathrm{EC}_{50} \mu \mathrm{g} / \mathrm{mL}\right)\end{array}$ & $2.36 \pm 0.15^{\mathrm{b}}$ & $4.03 \pm 0.45^{\mathrm{d}}$ & $2.46 \pm 0.46^{\mathrm{a}}$ & $2.16 \pm 0.05^{\mathrm{c}}$ & & $4,20 \pm 0,11$ & 3 & 1.27 & $0.348^{\mathrm{NS}}$ \\
\hline
\end{tabular}

$\mathrm{IC}_{50}$ and $\mathrm{EC}_{50}$ values represent the mean of three replicates $(n=3)$; letters (a-d) indicate significant differences at $P<0.05 .{ }^{* * *}$ Significant at $P<0.001 \%$. NS: not significant. df: degree of freedom, $F$ : Fisher value, and $P$ : probability.

TABLE 5: Antibacterial (IZ mm) and antifungal (\%I) activities of wormwood essential oil.

\begin{tabular}{|c|c|c|c|c|c|c|c|c|c|}
\hline & Boukornine & Jérissa & Kairouan & Bou Salem & df & $F$ & $P$ & Tetracycline & Nystatin \\
\hline \multicolumn{10}{|c|}{ Bacteria } \\
\hline $\begin{array}{l}\text { Staphylococcus aureus } \\
25923\end{array}$ & $20.66 \pm 2.61^{\mathrm{b}}$ & $20.66 \pm 0.65^{\mathrm{b}}$ & $25 \pm 1.13^{\mathrm{a}}$ & $18 \pm 1.13^{\mathrm{c}}$ & 3 & 2.05 & $0.184^{\mathrm{NS}}$ & $25 \pm 2.56$ & \\
\hline $\begin{array}{l}\text { Staphylococcus } \\
\text { methicillin-resistant }\end{array}$ & $15.00 \pm 1.13^{\mathrm{b}}$ & $14.33 \pm 0.65^{\mathrm{c}}$ & $16 \pm 1.30^{\mathrm{a}}$ & $14.33 \pm 0.65^{\mathrm{c}}$ & 3 & 0.21 & $0.879^{\mathrm{NS}}$ & $25 \pm 2.54$ & \\
\hline $\begin{array}{l}\text { Listeria } \\
\text { monocytogenesATCC } 19195\end{array}$ & $18.66 \pm 2.35^{\mathrm{b}}$ & $17.33 \pm 1.72^{\mathrm{c}}$ & $20.00 \pm 1.95^{\mathrm{a}}$ & $20.00 \pm 1.13^{\mathrm{a}}$ & 3 & 0.53 & $0.674^{\mathrm{NS}}$ & $24 \pm 2.42$ & \\
\hline \multicolumn{10}{|c|}{ Fungi } \\
\hline Fusarium graminearum & $14.66 \pm 0.57^{\mathrm{c}}$ & $23.65 \pm 0.57^{\mathrm{a}}$ & $11.11 \pm 0.12^{\mathrm{d}}$ & $16.66 \pm 0.57^{\mathrm{b}}$ & 3 & 18.57 & $0.000^{* * *}$ & & $25 \pm 2.31$ \\
\hline Fusarium culmorum & $45.23 \pm 3.11^{\mathrm{b}}$ & $23.65 \pm 0.57^{\mathrm{d}}$ & $42.06 \pm 0.57^{\mathrm{c}}$ & $46.82 \pm 0.57^{\mathrm{a}}$ & 3 & 32.77 & $0.000^{* * *}$ & & $25 \pm 2.14$ \\
\hline Fusarium oxysporum & $19.04 \pm 0.57^{\mathrm{c}}$ & $27.58 \pm 2.55^{\mathrm{a}}$ & $17.94 \pm 0.57^{\mathrm{d}}$ & $25.28 \pm 0.57^{\mathrm{b}}$ & 3 & 7.79 & $0.009^{* *}$ & & $20 \pm 1.67$ \\
\hline Sclerotinia & nd & $23.61 \pm 2.12$ & nd & nd & 3 & 185.81 & $0.000^{* * *}$ & & $22 \pm 2.01$ \\
\hline Rhizoctonia solani & nd & $25.39 \pm 0.57$ & nd & nd & 3 & 77.35 & $0.000^{* * *}$ & & $20 \pm 1.78$ \\
\hline
\end{tabular}

Results are the mean of three replications. The diameter of disc was $6 \mathrm{~mm}$. Values with different superscripts (a-d) are significantly different at $P<0.05$. nd: not detected. NS: not significant. df: degree of freedom, $F$ : Fisher value, and $P$ : probability. ${ }^{* *} P<0.01$. ${ }^{* * *} P<0.001$.

the antiradical activity of Lamiaceae and total polyphenols demonstrating the importance of these compounds in the antioxidant activity of extracts of spices and their significant contribution to the total antioxidant activity.

3.6. Reducing Power. The ability of methanol extracts of wormwood aerial parts collected from four regions to reduce the metal ions was evaluated by determining the $\mathrm{CE}_{50}$ corresponding to the concentration of the extract to an absorbance of 0.5. The ascorbic acid has been used as a positive control. The results in Table 4 showed that the methanol extracts of wormwood aerial parts were characterized by $\mathrm{EC}_{50}$ values lower than that of the positive control: ascorbic acid $\left(\mathrm{EC}_{50}=\right.$ $4.2 \pm 0.11 \mu \mathrm{g} / \mathrm{mL}$ ). In addition, statistical analysis showed that there is no effect of region on the activities of the methanol extracts.

3.7. Antibacterial Activity. The test results of the antibacterial effect are summarized in Table 5. The results show that the diameter of the inhibition zone is not affected by the region factor. The essential oils of wormwood at different regions showed an interesting antibacterial activity. Indeed, the highest activity was observed against Staphylococcus aureus strain with a diameter of inhibition equal to $25 \pm$ $1.13 \mathrm{~mm}$ for the essential oil of Kairouan; this strain had a lower sensitivity to the EO of Bou Salem region (IZ $=18 \pm$ $1.13 \mathrm{~mm}$ ). Essential oils of Boukornine and Jérissa regions show a moderately antibacterial activity $(I Z=20.66 \mathrm{~mm})$. In agreement with our results, the EO of wormwood aerial parts growing in Canada has a high activity against Staphylococcus aureus ( $\mathrm{IZ}=25 \pm 1.4 \mathrm{~mm}$ ) which was greater than the positive control (methicillin activity IZ $=18 \pm 1.0 \mathrm{~mm}$ ) [34]. Essential oils of Bou Salem and Kairouan have the same activity against Listeria monocytogenes ( $\mathrm{IZ}=20 \mathrm{~mm}$ ), but the $\mathrm{EO}$ of Jérissa and Boukornine is less active $(\mathrm{IZ}=18 \mathrm{~mm})$. These results show that wormwood essential oil was endowed with a significant antibacterial activity that is closely related to the organoleptic quality of the oil, which in turn depends strongly on the collection region of plant material.

3.8. Antifungal Activity. The results of the antifungal activity of essential oils of absinthe are summarized in Table 5. Wormwood EOs had a significant inhibitory activity against the three phytopathogenic F. graminearum, F. culmorum, and F. oxysporum while only EO of Jérissa proved to be active against Sclerotinia $(23.61 \pm 2.12 \%)$ and Rhizoctonia solani $(25.39 \pm 0.57 \%)$. As for the antibacterial activity, antifungal activity could be attributed to the major component of essential oil of wormwood: chamazulene [56]. Meanwhile, it has been shown that the chamazulene possesses significant antifungal activity [57]. The antimicrobial effect of EOs of absinthe gives them an important role in the fields of food, cosmetics, and pharmaceutical industries. In addition $A$. absinthium L. EO from France containing ( $Z$ )-epoxyocimene and chrysanthenyl acetate as major components inhibited the growth of both the yeasts Candida albicans and Saccharomyces cerevisiae var. chevalieri [4]. Wormwood EO from a Turkish population, whose main components are 
camphor, 1,8-cineole, and chamazulene, has been described as fungicidal against 34 species of fungi including F. solani and F. oxysporum [3]. Furthermore, A. absinthium EO from Uruguay rich in thujone showed antifungal effects against Alternaria sp. and Botrytis cinerea [58]. However, further studies are needed to identify the compound(s) responsible for the antifungal effects of $A$. absinthium L. EOs.

\section{Conflict of Interests}

The authors declare that there is no conflict of interests.

\section{References}

[1] K. S. Bora and A. Sharma, "The genus Artemisia: a comprehensive review," Pharmaceutical Biology, vol. 49, no. 1, pp. 101-109, 2011.

[2] K. S. Bora and A. Sharma, "Phytochemical and pharmacological potential of Artemisia absinthium Linn. and Artemisia asiatica Nakai: a review," Journal of Pharmacy Research, vol. 3, no. 2, pp. 325-328, 2010.

[3] S. Kordali, R. Kotan, A. Mavi, A. Cakir, A. Ala, and A. Yildirim, "Determination of the chemical composition and antioxidant activity of the essential oil of Artemisia dracunculus and of the antifungal and antibacterial activities of Turkish Artemisia absinthium, A. dracunculus, Artemisia santonicum, and Artemisia spicigera essential oils," Journal of Agricultural and Food Chemistry, vol. 53, no. 24, pp. 9452-9458, 2005.

[4] F. Juteau, I. Jerkovic, V. Masotti et al., "Composition and antimicrobial activity of the essential oil of Artemisia absinthium from Croatia and France," Planta Medica, vol. 69, no. 2, pp. 158-161, 2003.

[5] H. Chiasson, A. Bélanger, N. Bostanian, C. Vincent, and A. Poliquin, "Acaricidal properties of Artemisia absinthium and Tanacetum vulgare (Asteraceae) essential oils obtained by three methods of extraction," Journal of Economic Entomology, vol. 94, no. 1, pp. 167-171, 2001.

[6] K. A. Tariq, M. Z. Chishti, F. Ahmad, and A. S. Shawl, "Anthelmintic activity of extracts of Artemisia absinthium against ovine nematodes," Veterinary Parasitology, vol. 160, no. 1-2, pp. 83-88, 2009.

[7] S. Irshad, M. Butt, and Y. Hira, "In-vitro antibacterial activity of two medicinal plants neem (Azadirachta indica) and peppermint," International Research Journal of Pharmaceuticals, vol. 1, no. 1, pp. 9-14, 2011.

[8] A.-U. H. Gilani and K. H. Janbaz, "Preventive and curative effects of Artemisia absinthium on acetaminophen and CCl4induced hepatotoxicity," General Pharmacology, vol. 26, no. 2, pp. 309-315, 1995.

[9] M. Mahmoudi, M. A. Ebrahimzadeh, F. Ansaroudi, S. F. Nabavi, and S. M. Nabavi, "Antidepressant and antioxidant activities of Artemisia absinthium L. at flowering stage," African Journal of Biotechnology, vol. 8, no. 24, pp. 7170-7175, 2009.

[10] J. M. Canadanovic-Brunet, S. M. Djilas, G. S. Cetkovic, and V. T. Tumbas, "Free-radical scavenging activity of wormwood (Artemisia absinthium L) extracts," Journal of the Science of Food and Agriculture, vol. 85, no. 2, pp. 265-272, 2005.

[11] Ö. Ertürk and U. Uslu, "Antifeedant, growth and toxic effects of some plant extracts on Leptinotarsa decemlineata (Say.) (Coleoptera, Chrysomelidae)," Fresenius Environmental Bulletin, vol. 16, no. 6, pp. 601-607, 2007.
[12] T. Jiratanan and R. H. Liut, "Antioxidant activity of processed table beets (Beta vulgaris var, conditiva) and green beans (Phaseolus vulgaris L.)," Journal of Agricultural and Food Chemistry, vol. 52, no. 9, pp. 2659-2670, 2004.

[13] J. N. Losso, F. Shahidi, and D. Bagchi, Anti-Angiogenic Functional and Medicinal Foods, Taylor \& Francis, Boca Raton, Fla, USA, 2007.

[14] B. N. Singh, B. R. Singh, R. L. Singh et al., "Oxidative DNA damage protective activity, antioxidant and anti-quorum sensing potentials of Moringa oleifera," Food and Chemical Toxicology, vol. 47, no. 6, pp. 1109-1116, 2009.

[15] A. Basile, S. Sorbo, B. Conte et al., "Antioxidant activity in extracts from Leptodictyum riparium (Bryophyta), stressed by heavy metals, heat shock, and salinity," Plant Biosystems, vol. 145, no. 1, pp. 77-80, 2011.

[16] M. Minutolo, I. Caruso, G. Caruso, P. Chiaiese, and A. Errico, "Establishment of Aster sedifolius and Aster caucasicus callus cultures as a potential source of antioxidants," Plant Biosystems, vol. 146, no. 1, pp. 41-46, 2012.

[17] P.-G. Pietta, "Flavonoids as antioxidants," Journal of Natural Products, vol. 63, no. 7, pp. 1035-1042, 2000.

[18] M. Friedman, P. R. Henika, and R. E. Mandrell, "Bactericidal activities of plant essential oils and some of their isolated constituents against Campylobacter jejuni, Escherichia coli, Listeria monocytogenes, and Salmonella enterica," Journal of Food Protection, vol. 65, no. 10, pp. 1545-1560, 2002.

[19] K. M. Schuenzel and M. A. Harrison, "Microbial antagonists of foodborne pathogens on fresh, minimally processed vegetables," Journal of Food Protection, vol. 65, no. 12, pp. 1909-1915, 2002.

[20] M. Sökmen, J. Serkedjieva, D. Daferera et al., "In vitro antioxidant, antimicrobial, and antiviral activities of the essential oil and various extracts from herbal parts and callus cultures of Origanum acutidens," Journal of Agricultural and Food Chemistry, vol. 52, no. 11, pp. 3309-3312, 2004.

[21] C. W. Wright, Artemisia, Taylor \& Francis, New York, NY, USA, 2002.

[22] A. Rezaeinodehi and S. Khangholi, "Chemical composition of the essential oil of Artemisia absinthium growing wild in Iran," Pakistan Journal of Biological Sciences, vol. 11, no. 6, pp. 946-949, 2008.

[23] E. Derwich, Z. Benziane, and A. Boukir, "Chemical compositions and insectisidal activity of essential oils of three plants Artemisia SP: Artemisia herba-alba, Artemisia absinthium and Artemisia Pontica (Morocco)," Electronic Journal of Environmental, Agricultural and Food Chemistry, vol. 8, no. 11, pp. 12021211, 2009.

[24] L. Martín, A. M. Mainar, A. González-Coloma, J. Burillo, and J. S. Urieta, "Supercritical fluid extraction of wormwood (Artemisia absinthium L.)," Journal of Supercritical Fluids, vol. 56, no. 1, pp. 64-71, 2011.

[25] Council of Europe, European Pharmacopoeia, Council of Europe, Strasbourg, France, 3rd edition, 1997.

[26] J.-L. Mau, C.-N. Chang, S.-J. Huang, and C.-C. Chen, "Antioxidant properties of methanolic extracts from Grifola frondosa, Morchella esculenta and Termitomyces albuminosus mycelia," Food Chemistry, vol. 87, no. 1, pp. 111-118, 2004.

[27] V. Dewanto, W. Xianzhong, K. K. Adom, and R. H. Liu, "Thermal processing enhances the nutritional value of tomatoes by increasing total antioxidant activity," Journal of Agricultural and Food Chemistry, vol. 50, no. 10, pp. 3010-3014, 2002. 
[28] B. Sun, J. M. Ricardo-da-Silva, and I. Spranger, "Critical factors of vanillin assay for catechins and proanthocyanidins," Journal of Agricultural and Food Chemistry, vol. 46, no. 10, pp. 42674274, 1998.

[29] T. Hatano, H. Kagawa, T. Yasuhara, and T. Okuda, "Two new flavonoids and other constituents in licorice root: their relative astringency and radical scavenging effects," Chemical and Pharmaceutical Bulletin, vol. 36, no. 6, pp. 2090-2097, 1988.

[30] M. Oyaizu, "Studies on products of browning reaction: antioxidative activity of products of browning reaction," The Japanese Journal of Nutrition, vol. 44, no. 6, pp. 307-315, 1986.

[31] J. L. Ríos and M. C. Recio, "Medicinal plants and antimicrobial activity," Journal of Ethnopharmacology, vol. 100, no. 1-2, pp. 8084, 2005.

[32] Statsoft, STATISTICA for Windows (Computer Program Electronic 703 Manual), Statsoft Inc, Tulsa, Okla, USA, 1998.

[33] A. Orav, A. Raal, E. Arak, M. Müürisepp, and T. Kailas, "Composition of the essential oil of Artemisia absinthium L. of different geographical origin," Proceedings of the Estonian Academy of Sciences, Chemistry, vol. 55, no. 3, pp. 155-165, 2006.

[34] D. Lopes-Lutz, D. S. Alviano, C. S. Alviano, and P. P. Kolodziejczyk, "Screening of chemical composition, antimicrobial and antioxidant activities of Artemisia essential oils," Phytochemistry, vol. 69, no. 8, pp. 1732-1738, 2008.

[35] K. Msaada, K. Hosni, M. B. Taarit, T. Chahed, M. E. Kchouk, and B. Marzouk, "Changes on essential oil composition of coriander (Coriandrum sativum L.) fruits during three stages of maturity," Food Chemistry, vol. 102, no. 4, pp. 1131-1134, 2007.

[36] K. Msaada, M. B. Taarit, K. Hosni, M. Hammami, and B. Marzouk, "Regional and maturational effects on essential oils yields and composition of coriander (Coriandrum sativum L.) fruits," Scientia Horticulturae, vol. 122, no. 1, pp. 116-124, 2009.

[37] K. Msaada, K. Hosni, M. B. Taarit, O. Ouchikh, and B. Marzouk, "Variations in essential oil composition during maturation of coriander (Coriandrum sativum 1.) Fruits," Journal of Food Biochemistry, vol. 33, no. 5, pp. 603-612, 2009.

[38] K. Masada, K. Hosni, M. Ben Taarit, M. Hammami, and B. Marzouk, "Effects of crop season and maturity stages on the yield and composition of essential oil of coriander (Coriandrum sativum L.) fruit," Medicinal and Aromatic Plant Science and Biotechnology, vol. 6, no. 1, pp. 115-122, 2012.

[39] K. Msaada, M. B. Taârit, K. Hosni et al., "Comparison of different extraction methods for the determination of essential oils and related compounds from coriander (Coriandrum sativum L.)," Acta Chimica Slovenica, vol. 59, no. 4, pp. 803-813, 2012.

[40] S. Kordali, A. Cakir, A. Mavi, H. Kilic, and A. Yildirim, "Screening of chemical composition and antifungal and antioxidant activities of the essential oils from three Turkish Artemisia species," Journal of Agricultural and Food Chemistry, vol. 53, no. 5, pp. 1408-1416, 2005.

[41] B. M. Lawrence, "Progress in essential oils," Perfumer \& Flavorist, vol. 17, pp. 39-42, 1992.

[42] W. C. Evans, Trease and Evans'Pharmacognosy, Saunders, Edinburgh, UK, 15th edition, 2000.

[43] N. Salem, K. Msaada, G. Hamdaoui, F. Limam, and B. Marzouk, "Variation in phenolic composition and antioxidant activity during flower development of safflower (Carthamus tinctorius L.)," Journal of Agricultural and Food Chemistry, vol. 59, no. 9, pp. 4455-4463, 2011.

[44] H. Monica, A. Moisuc, F. Radu, S. Drăgan, and I. Gergen, "Total polyphenols content determination in complex matrix of medicinal plants from Romania by nir spectroscopy," Bulletin of the University of Agricultural Sciences and Veterinary Medicine Cluj-Napoca Agriculture, vol. 65, no. 1, pp. 123-128, 2008.

[45] M. A. Ebrahimzadeh, S. F. Nabavi, S. M. Nabavi, and F. Pourmorad, "Nitric oxide radical scavenging potential of some Elburz medicinal plants," African Journal of Biotechnology, vol. 9, no. 32, pp. 5212-5217, 2010.

[46] M. Sengul, S. Ercisli, H. Yildiz, N. Gungor, A. Kavaz, and B. Çetina, "Antioxidant, antimicrobial activity and total phenolic content within the aerial parts of artemisia absinthum, Artemisia santonicum and Saponaria officinalis," Iranian Journal of Pharmaceutical Research, vol. 10, no. 1, pp. 49-56, 2011.

[47] A. Wojdyło, J. Oszmiański, and R. Czemerys, "Antioxidant activity and phenolic compounds in 32 selected herbs," Food Chemistry, vol. 105, no. 3, pp. 940-949, 2007.

[48] A. Dapkevicius, T. A. Van Beek, G. P. Lelyveld et al., "Isolation and structure elucidation of radical scavengers from Thymus vulgaris leaves," Journal of Natural Products, vol. 65, no. 6, pp. 892-896, 2002.

[49] K. Aaby, E. Hvattum, and G. Skrede, "Analysis of flavonoids and other phenolic compounds using high-performance liquid chromatography with coulometric array detection: relationship to antioxidant activity," Journal of Agricultural and Food Chemistry, vol. 52, no. 15, pp. 4595-4603, 2004.

[50] G.-Q. Zheng, "Cytotoxic terpenoids and flavonoids from Artemisia annua," Planta Medica, vol. 60, no. 1, pp. 54-57, 1994.

[51] C. A. Rice-Evans, N. J. Miller, and G. Paganga, "Structureantioxidant activity relationships of flavonoids and phenolic acids," Free Radical Biology and Medicine, vol. 20, no. 7, pp. 933956, 1996.

[52] H.-G. Lee, H. Kim, W.-K. Oh et al., “Tetramethoxy hydroxyflavone p7F downregulates inflammatory mediators via the inhibition of nuclear factor $\kappa \mathrm{B}$," Annals of the New York Academy of Sciences, vol. 1030, pp. 555-568, 2004.

[53] S. Kordali, I. Aslan, O. Çalmaşur, and A. Cakir, "Toxicity of essential oils isolated from three Artemisia species and some of their major components to granary weevil, Sitophilus granarius (L.) (Coleoptera: Curculionidae)," Industrial Crops and Products, vol. 23, no. 2, pp. 162-170, 2006.

[54] A. Braca, G. Fico, I. Morelli, F. de Simone, F. Tomè, and N. De Tommasi, "Antioxidant and free radical scavenging activity of flavonol glycosides from different Aconitum species," Journal of Ethnopharmacology, vol. 86, no. 1, pp. 63-67, 2003.

[55] Y.-Y. Soong and P. J. Barlow, "Quantification of gallic acid and ellagic acid from longan (Dimocarpus longan Lour.) seed and mango (Mangifera indica L.) kernel and their effects on antioxidant activity," Food Chemistry, vol. 97, no. 3, pp. 524-530, 2006.

[56] B. Bozin, N. Mimica-Dukic, M. Bogavac et al., "Chemical composition, antioxidant and antibacterial properties of Achillea collina Becker ex Heimerl s.l. and A. pannonica Scheele essential oils," Molecules, vol. 13, no. 9, pp. 2058-2068, 2008.

[57] B. Kedzia, "Antimicroorganisms activity of oil Chamomillae and its components," Herba Polonica, vol. 37, no. 1, pp. 29-38, 1991.

[58] M. L. Umpiérrez, M. E. Lagreca, R. Cabrera, G. Grille, and C. Rossini, "Essential oils from Asteraceae as potential biocontrol tools for tomato pests and diseases," Phytochemistry Reviews, vol. 11, no. 4, pp. 339-350, 2012. 

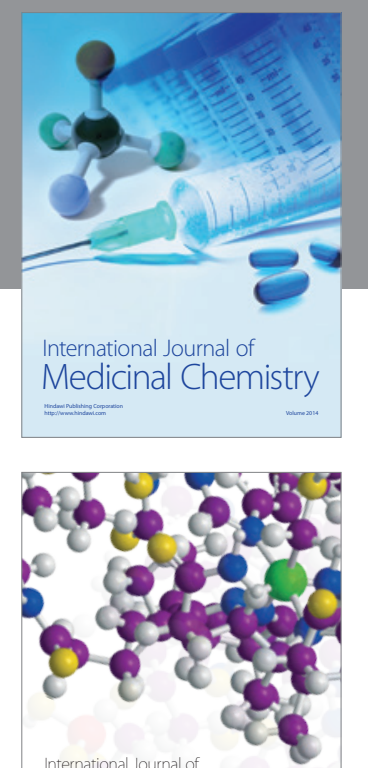

\section{Carbohydrate} Chemistry

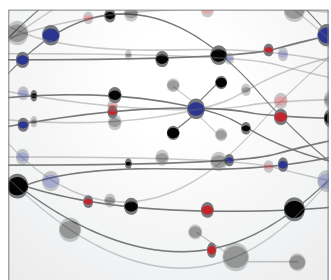

The Scientific World Journal
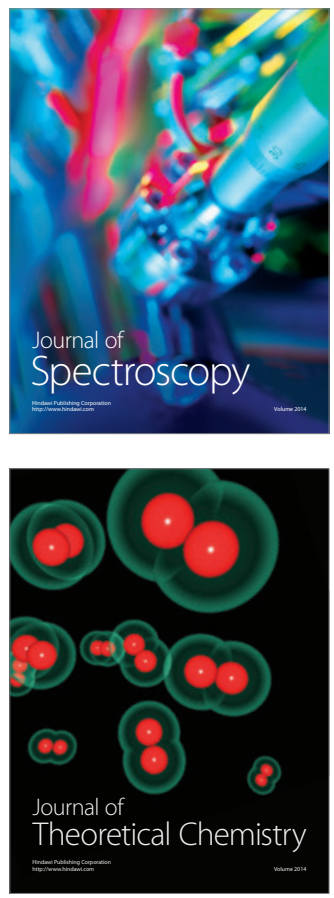
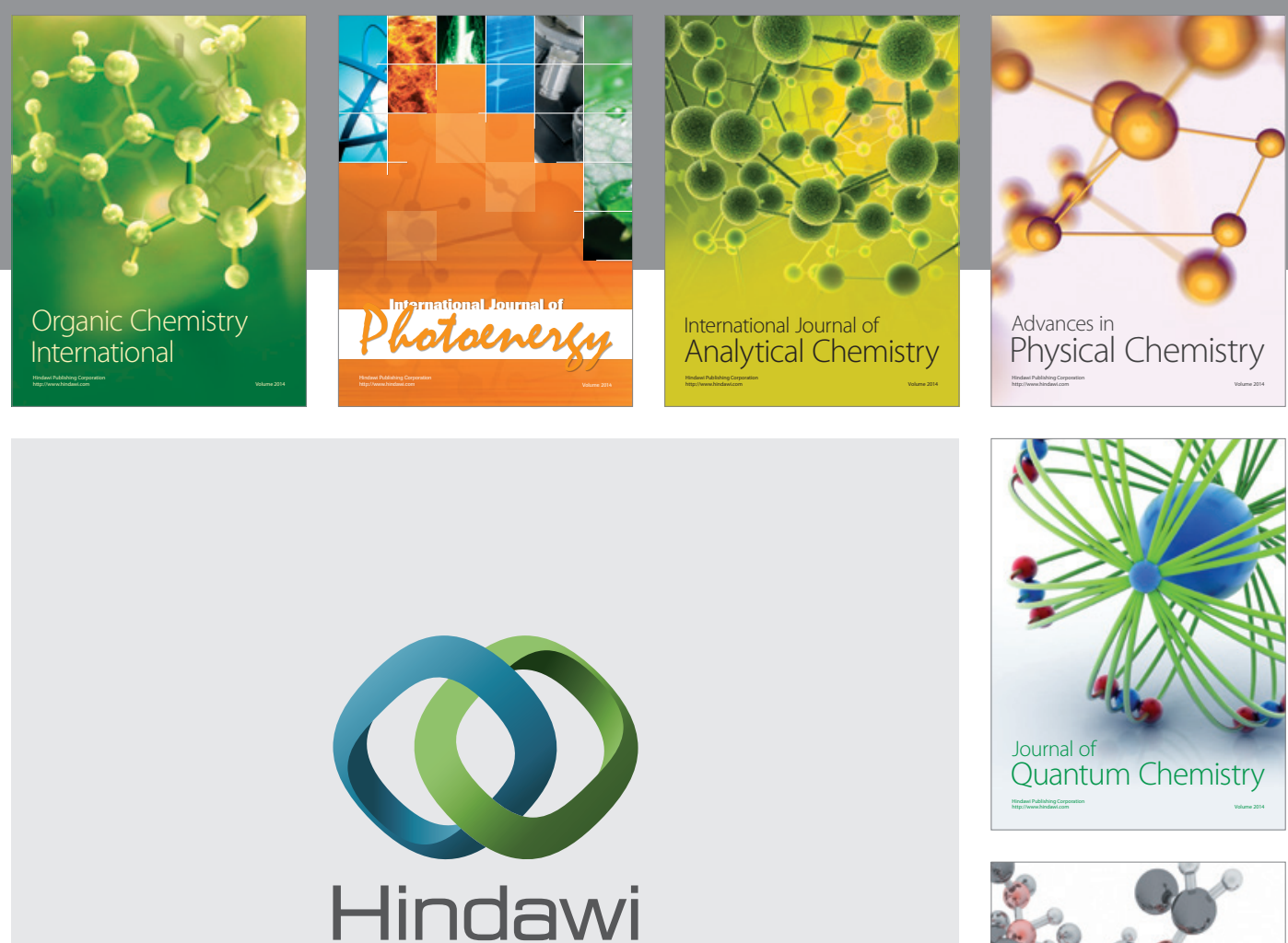

Submit your manuscripts at

http://www.hindawi.com

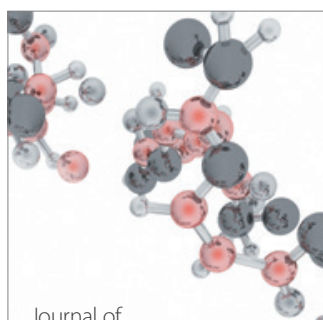

Analytical Methods

in Chemistry

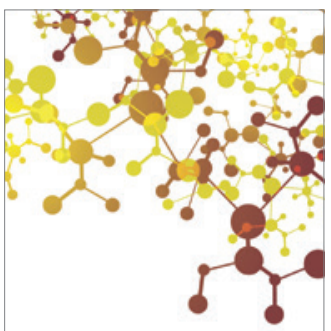

Journal of

Applied Chemistry

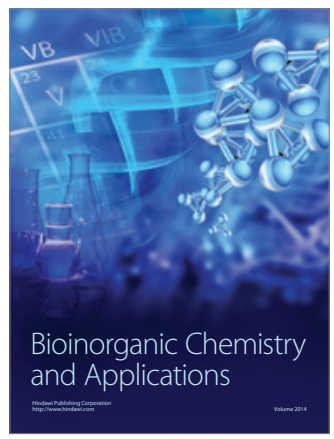

Inorganic Chemistry
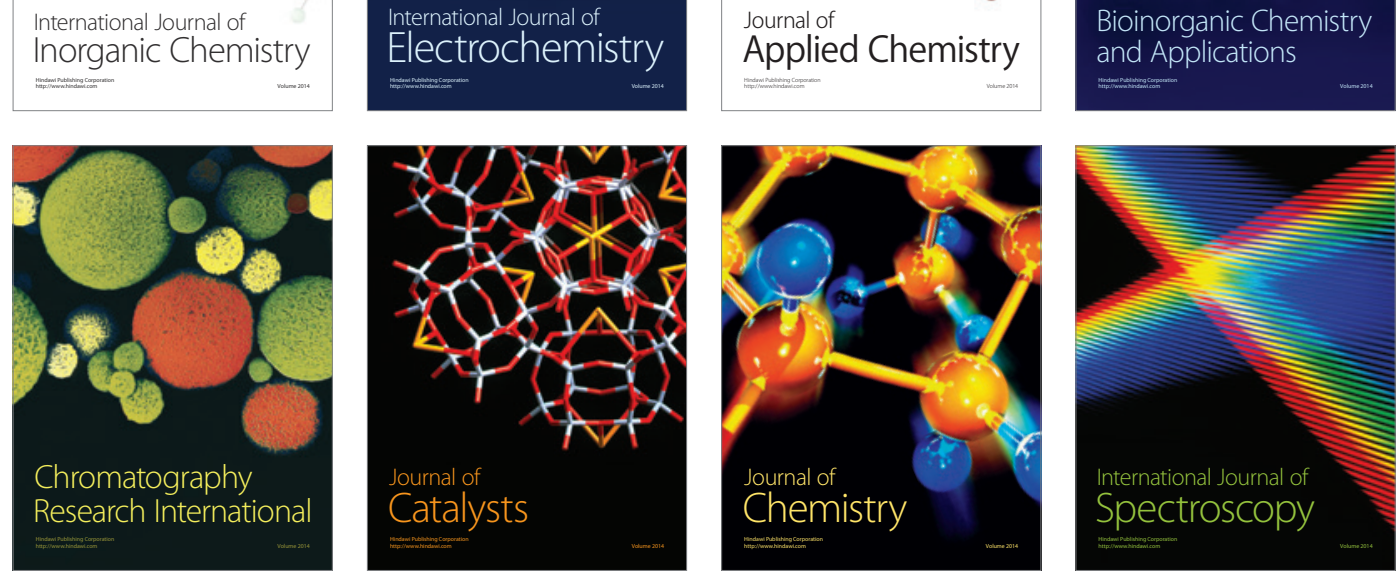